\title{
A TIME-SERIES ANALYSIS OF CRIME \\ AND DRUG USE IN NEW YORK CITY
}

Hope Corman

H. Naci Mocan

Working Paper 5463

\author{
NATIONAL BUREAU OF ECONOMIC RESEARCH \\ 1050 Massachusetts Avenue \\ Cambridge, MA 02138 \\ February 1996
}

This research is supported by a grant from the National Institute of Drug Abuse to the National Bureau of Economic Research (Grant No. 1-R03-DA06764). We thank Keith Amadio, Joseph Bucs, and Ronald Teodoro for their help in data collection, and Elena Pestchanskaia, Erdal Tekin, Melissa Anderson and especially Danny Rees for their assistance in data analysis. This paper is part of NBER's research program in Health Economics. Any opinions expressed are those of the authors and not those of the granting agency, Rider University, University of Colorado at Denver, or the National Bureau of Economic Research.

(c) 1996 by Hope Corman and H. Naci Mocan. All rights reserved. Short sections of text, not to exceed two paragraphs, may be quoted without explicit permission provided that full credit, including $\odot$ notice, is given to the source. 


\title{
A TIME-SERIES ANALYSIS OF CRIME AND DRUG USE IN NEW YORK CITY
}

\begin{abstract}
This report summarizes the results of a project which investigated the time series interrelationships between crime, drug use, police, and arrests in New York City. We use monthly data from 1970 through 1990 for New York City. We plot the individual time series for five different non-drug crimes, arrest rates for these crimes, drug deaths, number of police officers, and drug arrests in New York City. We find that drug usage, as proxied by drug deaths, increased from the mid-1980's to about 1988-1989. At the same time, felony drug arrests increased substantially. During the mid-1980's, there were increases in murders, assaults, and motor vehicle thefts. Robberies increased in the later 1980s and burglaries declined throughout the 1980s. Arrest rates and total arrests for non-drug crimes did not decline during this period of increased drug arrests.

In a multivariate analysis, we found that the three property crimes investigated - robberies, burglaries and motor vehicle thefts - increased when there were unexpected increases in drug usage. We did not find such a relationship between drug use and murders or assaults, holding constant arrest rates and police. In addition, we found evidence of police deterrence, either directly, or through arrests, of property-related and assault offenses, but not for murders. Thus, in a time-series approach, we are able to find a causal relationship between drug usage and property-related felonies.
\end{abstract}

Hope Corman

Department of Economics

Rider University

Lawrenceville, NJ 08648-3099

and NBER
H. Naci Mocan

Department of Economics

University of Colorado

Campus Box 181, PO Box 173364

Denver, CO 80217-3364

and NBER 


\section{A Time-Series Analysis of Crime, Drug Abuse and Deterrence in New York City}

\section{Introduction}

In the course of the past decade, and into the 1990's the media has focused much attention on issues of drug abuse, crime control, and the criminal justice system. It has been portrayed that drug usage increased to epidemic levels since the introduction of crack cocaine in the early-to mid-1980's. It has also been concluded that the crime rates, particularly crimes involving violence, have soared as a result of the increased drug usage. In response to these two problems, there was a large increase in resources devoted to drug control and to the criminal justice system. ${ }^{1}$

The purpose of this study is twofold. First, it describes trends in drug use, police efforts to arrest individuals who commit non-drug felony offenses, size of the police force, and trends in crime rates over a long period of time and in one location ${ }^{2}$. The study utilizes a carefully constructed unique data set for New York City from 1970 until the 1990's. By evaluating the measured magnitudes, and timing of the events, we place these issues into more of an historical context, and base conclusions on the best available measures of the problems. By comparing magnitudes over such a long period of time, it is easier to isolate the small and short-lived changes from the large and long-lived ones.

In addition, the study provides insights into the causal relationship between drug usage and non-drug crimes. A crime supply function is estimated where both criminal justice sanctions and drug usage affect non-drug crime rates. In this framework, we can assess whether increases in drug usage result in increases in non-drug crime over time. Time-series data allow us to circumvent many of the problems found in cross-sectional studies. We also use recent advances in time-series econometrics to test and correct for problems previously found in time-series analyses of crime.

' See Rasmussen and Benson (1994) for a discussion of these trends.

2 Throughout this analysis, we refer to drug-related crime as acts related to the sale, purchase, or possession of illegal drugs. Non-drug crimes refer to illegal acts other than the sale, purchase, or possession of illegal drugs. 


\section{Prior Research}

Since Becker's (1968) ground-breaking theoretical work on the economics of crime, and since Ehrlich's $(1973,1975)$ empirical analyses, several economists have expanded upon both the theory and the empirical analysis of crime (Block and Heineke 1975, Witte 1980). According to the basic theoretical framework, individuals engage in criminal activities depending upon the expected payoffs of the criminal activity, the return to legal labor market activity, tastes, and the costs of criminal activity, such as those associated with apprehension, conviction and punishment. Excellent reviews of the literature appear in Chiricos (1987), Freeman (1983), Long and Witte (1981) and Nagin (1978). While some studies reported evidence that increasing criminal justice sanctions reduce criminal activity (Ehrlich 1975, Witte 1980, Layson 1985, Grogger 1991), others found weak or no relationship between the two (Myers 1983, Cover and Thistle 1988, Cornwell and Trumbull 1994).

Drug use has a natural place in this framework for a variety of reasons. First, drug use may directly alter an individual's behavior. For example, drugs may induce users to be more violent when under the influence or when the drug's effects are wearing off. Second, the expense of purchasing drugs may cause the individual to commit property-related offenses which would not have been committed had the person not needed the revenue to support the drug habit. Third, because the drug market is illegal and cannot be regulated by standard business law, the market may resort to non-drug crimes to enforce agreements or gain market share.

In addition, drug usage may affect non-drug crime in an indirect way. If increased drug usage causes increased levels of criminal justice resources devoted to drug crimes (such as more police officers being devoted to drug busts), this may reduce the probability of arrest for those who commit non-drug crimes. Similarly, if increased drug use results in prison crowding, this may yield to shorter incarceration periods and suspended sentences for those who commit non-drug crimes, generating a decay in deterrence, hence an incentive to commit more non-drug crime.

There is a voluminous literature on the relationship between drugs and non-drug crime. Papers by Goldstein (1985) Goldstein et al. (1991), Gropper (1985), McBride (1981) and Wish and Johnson (1986) refute previously held beliefs that heroin (and cocaine) users 
do not commit violent crimes. McBride (1981) and Goldstein (1985) both describe the drug market place as breeding violence because sellers fear being robbed and buyers fear being cheated. Neither party has legal recourse. These articles clearly show the covariation between violent crime and drug abuse. They do not, however establish causality over time, and they do not answer the question of whether periods of increased overall drug usage are associated with periods of increased non-drug criminal activity.

A few studies examined the relationship between non-drug crime and drug usage in the pre-crack era. Bachman and Witte (1980) investigated the effects of criminal justice sanctions and legal employment conditions on the number of subsequent arrests for three separate sub-samples of prison inmates-- heavy alcohol users, heavy drug users and non-users. They found that drug users are less sensitive to sanctions than non-drug users. Silverman and Spruill (1977) examined the effects of drug prices and clearance rates on crime rates for a time series of neighborhoods in Detroit. Although they base their results on only 33 months of observations, their paper does a good job in relating drug prices and legal sanctions to criminal activity in a multivariate context. Silverman and Spruill find that both property and personal crime rates increased with increased expenditures on heroin, and that arrests deter non-drug crimes.

Many of the recent studies relating drug policies to non-drug crime were conducted by the research group at Florida State University: Benson et al. (1992), Benson et al. (1994), Kim et al. (1993), Sollars et al. (1994), and Benson and Rasmussen (1991). They follow a Becker-type model in which potential criminals respond to incentives, and find that increased drug-related law enforcement activities in Florida led to a decrease in the expected punishment for non-drug crimes, generating increases in non-drug crimes. It should be noted that much of this work relies on time-series inferences from cross-sectional data. In a comparison of 1983-84 to 1986-87 Benson et al. observe a decrease in the deterrent effect of police activities over time and relate this to a decrease in the average prison term which resulted from overcrowding in Florida's prisons (Benson et al. 1991).

Kleiman (1988), Kleiman and Smith (1990), Moore (1990), Moore and Kleiman (1989), Reuter and Kleiman (1986), Rottenberg (1968) and White and Luksetich (1983) have discussed the special considerations of the market structure for an illegal good, specifically 
drugs. Both buyers and sellers face high risks in dealing with strangers: the participant may be violent, may steal or defraud, or may be a law enforcement official. More intensive street-level enforcement may cause supply and demand for drugs to decrease, with an indeterminate effect on price. Violence can result because new participants challenge established monopolies, or can result when markets must be re-established due to law enforcement. Kleiman finds some evidence that focused crack-downs on drugs can result in decreases in non-drug crime.

Gandossy (1980) reviewed over 600 articles on the relationship between drug usage and crime in order to assess the state of knowledge and gaps in the literature. Since then, Gropper (1985), Speckart and Anglin (1986) and Wish and Johnson (1986) have provided updates. In their review of recent studies on the reiationship between drug abuse and predatory crime, Chaiken and Chaiken (1990) present surprisingly guarded conclusions stating that "...there appears to be no simple general relation between high rates of drug use and high rates of crime." These results are based on studies using some of the best individual data available. In the policy recommendations of these authors, they suggest that programs targeted at heavy drug users might be a more effective way to reduce predatory crime than a general program to decrease overall drug usage. This is because heavy drug users commit more crimes and for longer time periods than other offenders. Harrison (1992), in another literature review, comes to similar conclusions, that the causal link between non-drug crime and drug usage has not yet been established, although the two appear to be correlated.

Overall, previous research has indicated that drug use is, generally, positively related to non-drug crime, both of a property and violent nature, although there is no general consensus on the issue. Similarly, there is some disagreement on whether increased law enforcement aimed at reducing drug usage has a positive or a negative impact on non-drug crime.

\section{Description of the Data}

This study utilizes a unique data set, which is constructed using records of the Crime Analysis Unit of the New York City Police Department (NYPD), the Office of 
Management Analysis and Planning of the NYPD, and the New York City Department of Health. The Crime Analysis Unit of NYPD has collected consistent monthly data on crime commission and arrests since 1970. These data form the core of our data set. Almost all of the research which investigates non-drug crime has focused on "index" crime offenses. These are the seven felony offenses for which the FBI collects data nation-wide: murder, felonious assault, rape, robbery, burglary, grand larceny, and auto theft. We examine all but two of these offenses: rape and grand larceny. We exclude rape because there is reason to believe that reporting frequencies vary significantly over time, ${ }^{3}$ and murder and assault are both indicators of violence. Furthermore, the purpose of this research is to relate drug usage to non-drug crime, while rape traditionally has not been linked to drug usage. We exclude grand larceny because the definition of this crime has changed over time. The change in New York State law in 1986 increased the value of the damage from $\$ 100$ to $\$ 250$ to be included into the category of grand larceny. ${ }^{4}$ This particular change, as well as the decrease in real value over time due to inflation influence the reporting rates and the categorization of this crime.

The monthly number of arrests by crime category are also obtained from the Crime Analysis Unit of NYPD. The data on the number of police officers are obtained from the Office of Management Analysis and Planning of the NYPD. The data obtained from the NYPD span the period January 1970-December 1990. The prevalence of drug usage is proxied by the number of deaths in New York City which are due to drug poisoning. These data are obtained from the New York City Health Department, and cover the period 19701990. Although the codes allow the coroner to specify the type of drug, the vast majority of cases were coded as drug type unknown. Therefore, we cannot disaggregate drug deaths by type of drug. Some researchers have used drug arrests as proxies for the prevalence of drug usage. They assume that police respond to crimes they find occurring, rather than setting policies over how to allocate enforcement resources. Because we consider drug arrests

${ }^{3}$ See Galvin (1985) for a discussion of changes in reporting of rape crimes over time.

${ }^{4}$ Source: New York City Police Deparment Crime Analysis Unit personal communication. 
decision variables on the part of the police, we do not use arrest data as proxies for drug usage. $s$

A significant issue in examining drug usage and crime is finding an appropriate rate of commission. The convention is to use the size of the population in the denominator to calculate the crime rates. Almost all population estimates for New York City are based on the decennial census figures. In the period from 1970 to 1990 , data indicate that New York City population went from 7.9 million to 7.1 million and back up to 7.3 million. There is considerable controversy about the magnitude of the undercounting problem, and how this problem may have changed over time. Because of the potential problem of undercounting and because the New York City population figures did not change dramatically during these time periods, we use actual crimes committed rather than the rates.

\section{Trends in Drug Usage. Crime and Criminal Justice}

Table 1 presents a brief description and mean values for the variables in the analysis. All time series relate to New York City and present monthly data from January of 1970 until December of 1990. The graphs presented in Figures 1-14 include the actual values of the variables, represented by the jagged line, along with the underlying trend component, represented as a smooth line. The trend component enables the reader to visualize the long-term swings of the variable under investigation, with most of the noise eliminated. We calculate the trend components using the Hodrick-Prescott filter. ${ }^{6}$

${ }^{5}$ In fact, in our data, drug deaths are correlated between .600 and .625 with our three drug arrest measures, indicating that drug arrests may be reasonable proxies for drug usage in New York City in studies which do not focus on police allocation issues.

6 We used the Hodrick-Prescott filter (Hodrick and Prescott, 1980) to obtain the slowly evolving trend component. In this procedure, the trend component in the variable under investigation, it, is obtained by solving the following convex minimization problem.

$$
\min \sum_{t=1}^{T}\left(X_{t}-\tau\right)^{2}+\lambda \sum_{t=3}^{T}\left(X_{t}-2 \tau_{t-1}+\tau_{t-2}\right)^{2}
$$

where $X$ is the variable of interest, and $\lambda$ is the weight on squared second difference of growth component, which penalizes acceleration in the trend. Following previous examples (e.g. Blackburn and 


\section{DRUg USAGE IN NEW YORK CITY}

There is evidence that the drugs of choice in New York City varied over the time period analyzed in this study. According to Johnson and Muffler (1992), there were three "drug epidemics" during this time span: the heroin injection era (1965-1973), the cocaine and freebase era (1975-1984) and the crack era (1985-at least 1990). According to the drug deaths pattern described in Figure 1, drug usage declined between 1970 and 1978. It rose after 1979, reaching a plateau in the first half of the 1980s. It began rising again around 1985 , reaching a peak in 1988, then declined again. The mean monthly value for the 1970's was 46 drug related deaths per month, whereas the mean monthly value for the 1980's was 61 -- an increase of about $32 \%$. In the peak year of 1988 there were an average of 101 drug deaths per month compared to 72 in the previous peak year of 1971-- an increase of almost $40 \%$. If the first and third "drug epidemics" result in more deaths than the middle one, then this picture is similar to the one painted by Johnson and Muffler (1992), cited above.

The drug deaths data presented in Figure 1 has the advantage of not requiring honest self-reporting, but it relies upon accurate diagnoses by medical personnel. At the beginning of the crack era, before many medical doctors were aware of the drug, some of the deaths may have been diagnosed as non-drug related. As the awareness increased, the probability of missing the drug usage as a cause should have decreased. Thus, the drug death data may underestimate the prevalence of the drug use around 1985, where crack was first introduced to the market. Despite this difficulty, this is best available drug use proxy on a population basis, which is consistently reported over the period of 1970-1990.

\section{POLICE ForCe AND ARRESTS FOR NON-DRUg CRRMES}

Figure 2 presents the number of police officers in New York City over time. The steep decline between the mid-1970's and early 1980's was due to the fiscal crisis in New York City. Due to lay-off and attrition, the police force declined from a peak of about 32,000 in 1970 to a trough of under 22,000 in the early 1980 's, a drop of about one-third.

Ravn 1992), $\lambda$ is set to be 1600 , but the decomposition was not sensitive to the variations in the value of $\lambda$. 
The police force had been increased to about 27,000 by the end of 1990 , only half the difference from its former peak.

Police actions against non-drug crimes is the arrest rate, measured as number of arrests divided by number of complaints. Recent research by Benson et al. (1992) indicates that, in Florida, increased police activity relating to drug offenses resulted in a decrease in police activities relating to non-drug crime. This caused decreases in arrest rates for non-drug crime, resulting in increases in these crimes. Did New York City experience the same drop in non-drug arrests as occurred in Florida? Arrest rates for murder, assault , robbery, burglary, and auto theft are presented in Figures 3 through 7 . During the period of 1975 to 1980, when the number of police officers declined, arrest rates for the five non-drug crimes, cited above, remained fairly constant. In addition, the drop in the number of officers between 1975 and 1980 did not coincide with a drop in the number of arrests for the seven FBI index crimes, as shown in Figure 8. Nor did arrest rates for these crimes experience dramatic increases coincidental with the increase in the size of the police force. Arrest rates for these five crimes exhibit no marked drops during the latter half of the 1980's, when drug arrests increased sharply. Thus, increased drug arrests did not coincide with declines in non-drug arrest rates in New York City.

\section{Non-DRUg CRIME IN NeW YoRK CITY}

Figures 9-13 present the number of complaints for five felony crimes: murder, assault, robbery, burglary, and auto theft. It is believed that increased drug usage is related to increases in criminal activity. However, intervening factors may affect both. Three important intervening factors are: the drop in price of cocaine, the availability of crack, and the increased law enforcement efforts aimed at reducing the drug market. Drug prices may affect drug usage in either direction. If the main effect of a drop in prices is an increase in the number of drug users, and if individuals commit more crimes when they are using drugs, then non-drug crime may increase. ${ }^{7}$ The drop in prices could cause less crime, since users

7 Research on the consumption of addictive goods indicates that the price elasticity of such commodities is not small. Becker, Grossman and Murphy (1991) fit models of rational addiction to 
will need to commit less crimes in order to support their habits. If police resources are diverted from non-drug arrests or if probability or length of incarceration falls as a result of the increased drug enforcement, then non-drug crime could increase due to decreased deterrence. Finally, some researchers argue that when a new drug, such as crack cocaine, is introduced to the market, there will be an increase in violence associated directly with the drug market, which the new markets are established. Figure 9 displays the monthly number of murders from 1970 through 1990 . The mean value of murders for the first half of the 1980's was about 140, compared with a mean of 142 for the second half. The monthly number of murders did experience an up-turn around the same time as an upturn in drug use indicators.

Assaults (Figure 10), the other strictly violent crime, exhibit a seasonal cycle. Assaults increase in the spring and summer months. Similar to the behavior of murders, assaults increased after 1984, reaching a peak in 1989, and declined afterwards.

Robbery, burglary, and auto thefts are presented in Figures 11 through 13.

Robberies exhibit a cyclical behavior, where the latest upswing took place in 1988. Burglaries, presented in Figure 12, declined almost $40 \%$ between the first and the last half of the 1980's. While the number of burglaries remained fairly constant between 1985 and 1989, they started declining after 1989. By far, the largest increase in a property-related crime occurred for motor vehicle theft, a crime which has not, traditionally, been linked to drug usage. Figure 13 demonstrates that motor-vehicle thefts, which exhibit cyclical behavior similar to robberies and burglaries, increased dramatically after 1986 .

There exists a striking pattern in these data regarding turning points of drug use indicators and crime variables in the late 1980's. Figure 1 suggests that the prevalence of drug use increased after early-to-mid 1980s. The same data indicate that drug use started declining after 1988-1989. The crime data displayed in Figures 9-13 reveal that there were

cigarettes to a U.S. time series of State cross-sections for the period 1955-85. They find a sizable longrun price elasticity of demand of -0.77. Saffer and Chaloupka (1995) estimate that the participation price elasticity for heroin is about -0.90 to -0.80 and that the participation price elasticity for cocaine is about -0.55 to -0.36 . The price elasticities of demand for these two drugs are about -1.80 to -1.60 , and -1.10 to -0.72 , respectively. 
uptums in murders, assaults, robberies, and motor-vehicle thefts during the similar time periods and all of these crimes started declining after 1988-1990. Burglaries do not follow the same pattern, but one can easily speculate that burglaries would have continued to follow the downward trend which started in 1981, but the increase in drug use around mid 1980s stopped the decline in burglaries. After 1989 burglaries continued to go down, which is coincident with the decline in drug use proxies discussed above.

The relationships between crime variables and drug use suggested by the graphs are only speculative. The co-movement of drug use and criminal activity may be due to a third variable. For example, if police presence and police deterrence are negatively correlated with drug use and non-drug criminal activity, then the observed positive simple correlation between drug use and non-drug crime may be inflated. To isolate the impact of drug use net of other variables influencing crime, we present a multivariate statistical analysis over a twenty years period of time.

\section{Statistical Analysis}

As described by Cornwell and Trumbull (1994), ideally, the economic model of criminal behavior should be estimated with individual level data. Most studies that employed micro data analyzed the behavior of individuais released from prisons (Witte 1980, Schmidt and Witte 1984). These studies provide information on the impact of specific deterrence, which is the influence of punishment on future behavior of ex-offenders. General deterrence, on the other hand, is the discouragement of criminal activity in general, through sanctions applied by the criminal justice system (such as increased arrests). General deterrence is pertinent for ex-offenders as well as for those who have not been involved in criminal activity. The investigation of general deterrence hypothesis using micro data requires a random sample of population including both criminals and non-criminals. These type of data are very costly to amass. Consequently, there has been only one study to date that we are aware of which employed micro data to investigate the impact of general deterrence on criminal activity (Tauchen, Witte and Griesinger 1994); and aggregate data remain to be widely employed, where the unit of observation is a jurisdiction, city or the state (Sjoquist 1973, Phillips and Votey 1975, Furlong and Mehay 1981, Craig 1987, Cover and Thistle 
1988).

The main problem with cross-sectional data is that of identification. Criminal activity is part of a system of equations, where crime, the size of the police force and arrests are determined simultaneously. With cross sectional data, it is difficult to find enough exogenous variables that can be meaningfully excluded from various equations to make identification possible. As explained below, time-series data provides a solution to the problem of simultaneity. Time series data have the additional advantage of capturing the dynamics of criminal behavior, which would be impossible to obtain from cross-sectional data.

We estimate the following crime supply equation

(1) $\mathrm{CR}_{\mathrm{t}}=\mathrm{f}\left(\mathrm{POL}_{\imath}, \mathrm{DRUG}_{\mathrm{t}}, \mathrm{ARR}_{\mathrm{t}-\mathrm{i}}, \mathrm{DRUG}_{\mathrm{t} \cdot \mathrm{i}}, \mathrm{POL}_{\mathrm{t} \cdot \mathrm{i}}, \mathrm{CR}_{\mathrm{t}-\mathrm{i}}, \mathrm{POV}_{\mathrm{f}}\right)$, where $\mathrm{i}=1, \ldots, \mathrm{k}$

Equation (1) postulates that the current value of criminal activity (CR) depends on the current size of the police force (POL), current drug use (DRUG), the rate of poverty (POV), as well as past values of arrests (ARR), drug use, police force, and criminal activity. Note that the current value of arrests does not belong in Equation (1). The exclusion of the contemporaneous value of arrests from the crime equation helps to identify the crime equation. It also helps us avoid the simultaneity bias. Arrest is clearly one of the endogenous variables of the system, and it is meaningful to hypothesize that current arrests are influenced by the current level of criminal activity. As a result, a simultaneity bias is created if the contemporaneous value of arrests is included into the crime equation. Unlike many other studies that employed annual time-series, monthly observations of our data provides a justification for the exclusion of the current arrest from the crime equation. In annual data, an increase in arrest in time $t$ (year $t$ ) is expected to have an impact on criminal activity in the same time period (same year). However with monthly data it would be difficult to claim that an increase in arrests in month $t$ would give a signal to criminals and prospective criminals to alter their behavior in the same month. To the extent that it takes at least a month for the criminals to notice the change in arrest activity, crime should depend on lagged arrest. 
The use of lagged variables to avoid the simultaneity among variables is also acknowledged by other researchers. Fisher and Nagin (1978) describe the following system between crime $\left(C_{V}\right)$ and sanctions $\left(S_{V}\right)$

$$
\begin{aligned}
& \mathrm{C}_{\mathrm{t}}=\mathrm{a}+\mathrm{bS}_{\mathrm{t}-1}+\mathrm{e}_{\mathrm{t}} \\
& \mathrm{S}_{\mathrm{t}}=\mathrm{c}+\mathrm{dC}_{\mathrm{t}-1}+\mu_{\mathrm{t}}
\end{aligned}
$$

In this model an unexpected increase in criminal activity in time $t$ due to an increase in a will increase sanctions in time $t+1$. However, since the crime equation depends on past sanctions, there will be no simultaneity between $C_{t}$ and $S_{t}$. The exception, as Fisher and Nagin describe, emerges if the errors of the crime equation are serially correlated. For example consider first degree serial correlation in the errors; i.e $\mathrm{e}_{\mathrm{l}}=\rho \mathrm{e}_{\mathrm{h}-1}+\mathrm{v}_{\mathrm{b}}$, where $\rho$ is the autoregressive parameter and $v_{t}$ is the white noise error term. It is easy to show that:

$\operatorname{Cov}\left(\mathrm{e}_{1}, \mathrm{e}_{-1}\right)=E\left[\left(\rho \mathrm{e}_{\mathrm{h}-1}+\mathrm{v}_{\mathrm{v}}\right) \mathrm{e}_{\mathrm{r}-1}\right]=\rho \operatorname{Var}\left(\mathrm{e}_{\mathrm{l}}\right)$, given that $\mathrm{E}\left[\mathrm{v}_{1} \mathrm{e}_{\mathrm{e}}\right]=0$.

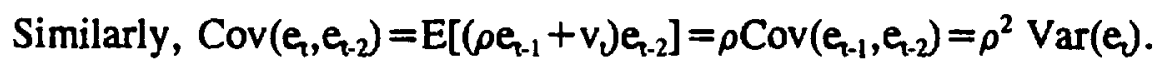

This implies that if $e_{1 \cdot 2}$ increases unexpectedly, this impacts $C_{t-2}$. Because the contemporaneous value of sanctions depends on the lagged value of crime, $S_{l-1}$ will also go up, if the parameter $d$ is positive. Because the covariance between $e_{t}$ and $e_{t-2}$ is non-zero, the increase in $e_{-2}$ will also impact $e_{t}$, which in turn will influence $C_{r}$. Since $S_{t-1}$ is also in equation (2a), this would create simultaneity between $S_{t-1}$ and $C_{t}$, which would produce biased parameter estimates.

Note that the simultaneity in this scenario is solely due to the autocorrelation in the errors of the crime equation. If $\mathrm{a}_{\mathrm{l}}$ is white noise $(\rho=0)$, there would not be any simultaneity between $C_{t}$ and $S_{t-1}$ within the framework described above. Including lagged values of the dependent variable to the right hand side of the crime equation and adding additional explanatory variables, such as the number of police officers and the drug use, allow us to extract information from the crime variable. Any potential autocorrelation in the errors is eliminated if the dynamics in crime variable is adequately captured, which is tested in the estimation section.

The empirical counterpart of equation (1) is 
(3)

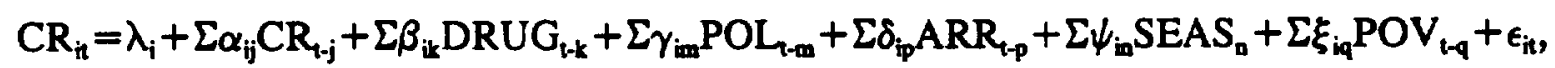

where $\mathrm{CR}_{\mathrm{i}}$ stands for $\mathrm{ith}$ crime ( $\mathrm{i}=1$ : Robbery, $\mathrm{i}=2$ : Burglary, etc.), and $\mathrm{j}, \mathrm{k}, \mathrm{m}, \mathrm{p}$ and $\mathrm{q}$ are the lag lengths of crime, drug deaths, the number of police officers, crime arrests, and poverty, respectively. $j \geq 1, k \geq 0, m \geq 0, p \geq 3, q \geq 0$. SEAS stands for monthly dummies to control for the impact of seasonality.

Equation (3) states that the number of crimes committed in time $t$ depends upon the past dynamics of the same criminal activity, the current and past values of drug use, the current and past values of the number of police officers, the past values of arrests, and the current and past values of the rate of poverty. Poverty is approximated by the number of cases of Aids to Families with Dependent Children (AFDC) in new York City, which is depicted in Figure 14. Note that arrests are lagged three months to avoid the simultaneity between crimes and arrests. Due to procedural lags, a change in criminal activity in a given month is not expected to prompt an adjustment in the size of the police force in the same month. Therefore the lag length of police in crime equation starts with zero. ${ }^{8}$

\section{TIME-SERIES ProperTIES OF THE VARIABLES}

It is well known that the usual techniques of regression analysis can result in highly misleading conclusion when variables contain stochastic trends (Stock and Watson 1988, Nelson and Kang 1984, Granger and Newbold 1974). If the variables under investigation are not governed by deterministic trends, a model where the crime variable is regressed on the levels of other variables and a time trend is misspecified. Under these conditions, as Nelson and Kang (1981) show, equation (3) not only produces a random $\mathbf{R}^{2}$, but the residuals from this regression exhibit spurious periodicity. Furthermore, inferences based on usual $t$ statistics are not valid (Stock and Watson 1988).

Variables with stochastic trends have long-memories, indicating that shocks on

8 Drug use, arrest, police force, and drug prices are other endogenous variables of the system. Lagged values of the endogenous variables are predetermined; the fiscal condition of New York City and the poverty rate are exogenous. 
these variables have impacts that do not die out quickly. This can be illustrated using the following example. Consider the first-order autoregressive process $\mathrm{X}_{t}=\alpha \mathrm{X}_{t-1}+\mathrm{e}_{t}$, where $\mathrm{e}_{\mathrm{t}}$ is a serially uncorrelated white noise series with zero mean and constant variance. $X_{t}$ is called a random walk if $\alpha=1$. It can easily be shown that $\mathrm{X}_{\mathrm{t}}=\Sigma \epsilon_{\mathrm{t}-\mathrm{i}} \mathrm{i}=0, \ldots, \infty$ if $\alpha=1$, which demonstrates that shocks (old and new) have permanent impacts on the current value of a random walk, exemplifying a long-memory. $X_{i}-X_{t-1}$, which is the first-difference of a random walk, is equal to $e_{1}$, and has a short-memory. Therefore, a random walk is called integrated of order one [I(1)], (or having a unit root), to indicate that it needs to be differenced once to achieve short-memory; consequently, a short memory series is integrated of order zero $[\mathrm{I}(0)]$.

If a variable is $I(0)$, it has a tendency to frequently return to, and cross, the mean value and any value a long way from the mean is inclined to be followed by values nearer to the mean. In contrast, an I(1) series has no tendency to move in any direction. It has no uniform or constant value to which it is attracted (Engle and Granger, 1991). Thus, an I(1) series contains stochastic trends.

Theoretically, there is no reason to expect that the number of crimes should fluctuate around a particular level, and visual inspection of Figures 9-13 suggests that it is likely that the crime variables are I(1) processes. To more formally test the hypothesis of stochastic trends, the following three versions of the augmented Dickey-Fuller test are applied.

$$
\begin{aligned}
& \Delta \mathrm{X}_{\mathrm{t}}=\lambda \mathrm{X}_{\mathrm{t}-1}+\Sigma \pi_{\mathrm{i}} \Delta \mathrm{X}_{\mathrm{t}-\mathrm{i}}+\mathrm{e}_{\mathrm{t}}, \\
& \Delta \mathrm{X}_{\mathrm{t}}=\mu+\lambda \mathrm{X}_{\mathrm{t}-1}+\Sigma \pi_{i} \Delta \mathrm{X}_{\mathrm{t}-\mathrm{i}}+\mathrm{e}_{\mathrm{t}}, \\
& \Delta \mathrm{Xt}=\mu+\eta \mathrm{t}+\lambda \mathrm{X}_{\mathrm{t}-\mathrm{i}}+\Sigma \pi_{\mathrm{i}} \Delta \mathrm{X}_{\mathrm{t}-\mathrm{i}}+\mathrm{e}_{\mathrm{t}},
\end{aligned}
$$

where $\mathrm{X}_{\mathrm{t}}$ is the series under investigation, $\Delta$ stands for the first-difference, and $i=1, \ldots, 12$. If $\lambda=0$, then $X_{t}$ contains a unit root and is therefore an $I(1)$ process. Since the estimated $\lambda$ does not have the usual asymptotic distribution, the values tabulated by MacKinnon (1991) are used, which are more accurate that the ones originally tabulated by Fuller (1976) and Dickey and Fuller (1981). Table 2 reports the calculated Dickey-Fuller 
statistic for the three specifications depicted in Equations 4A-4C. The calculated test statistic for felony assaults in model $4 \mathrm{~A}$ (without constant) exceeds the critical value, but application of the unit root tests using models $4 \mathrm{~B}$ (with constant) and $4 \mathrm{C}$ (with trend) reveal that the calculated statistics are smaller than the critical values. The only other instance of statistical significance occurs for AFDC cases when there is a constant but not a trend term. In all other instances, the calculated test statistics are smaller than the critical values. Thus, the hypothesis of a unit root (stochastic trend) cannot be rejected for any of the variables under consideration. ${ }^{9}$ This means the proper specification of Equation (2), which takes into account the recent developments in time-series econometrics, should involve regressing the first difference of crime variables on the first difference of police, drug use, arrests and AFDC cases, and should not include a time trend as a regressor.

Although the variables are governed by stochastic trends, if there exists a linear combination of them which is $\mathrm{I}(0)$ with zero mean, then they are cointegrated. In this case, there exists a common factor in all, and the variables do not diverge from one another in the long-run. Two versions of the cointegration test are performed by running the regressions

(5A) $\quad \mathrm{CR}_{\mathrm{it}}=\Omega_{0}+\Omega_{1} \mathrm{DRUG}_{\mathrm{t}}+\Omega_{2} \mathrm{POL}_{\mathrm{l}}+\Omega_{3} \mathrm{ARR}_{\mathrm{t}}+\Omega_{4} \mathrm{AFDC}_{\mathrm{t}}+\epsilon_{\mathrm{in}}$, and

(5B) $\quad \mathrm{CR}_{\mathrm{it}}=\Omega_{0}+\Omega_{1} \mathrm{DRUG}_{\mathrm{t}}+\Omega_{2} \mathrm{POL}_{\mathrm{t}}+\Omega_{3} \mathrm{ARR}_{\mathrm{t}}+\Omega_{4} \mathrm{AFDC}_{\mathrm{t}}+\Omega_{\mathrm{t}} \mathrm{t}+\epsilon_{\mathrm{it}}, \mathrm{i}=1, \ldots, 5$;

and investigating whether the residuals of Equations (4A) and (4B) contain a unit root. This is done by running the cointegration regression :

$$
\mathrm{e}_{\mathrm{i}, \mathrm{t}}=\eta \mathrm{e}_{\mathrm{i}, t-1}+\nu_{\mathrm{i}, \mathrm{t}}
$$

where $\mathrm{e}_{\mathrm{i}, \mathrm{t}}$ stands for the residuals of the regression (5A) or (5B) and $\nu_{\mathrm{i}, \mathrm{t}}$ is a white noise error term. If the estimated $\eta$ is zero, $e_{i, t}$ has a random walk behavior, which indicates that the variables, which are governed by stochastic trends, do not share a common trend; i.e they are not co-integrated. The estimated $t$-values for $\eta$ are reported in Table 3. In all cases,

${ }^{9}$ We also applied the procedure suggested by Mocan (1994) to investigate the existence of stochastic trends. The conclusions about the existence of unit roots remained the same. 
there is evidence of co-integration between crime, arrest, drug use and police force. ${ }^{10}$

\section{Results}

The summary of the regression results are presented in Table 4. Regressions have 252 monthly observations from January 1970 to December 1990 . The first column of Table 4 reports the results where the optimal lag-length for each variable is determined by Akaike Information Criterion (Akaike 1972). The natural logarithms of the variables are taken before differencing; thus the variables are in percent change form. Estimations are carried out using a heteroscedasticity and serial correlation robust covariance matrix with serial correlation up to lag six. Lagrange-multiplier tests are applied to investigate whether the residuals of the estimated models are white noise. The test statistics reported in Table 4, which are distributed as $\chi^{2}$ with six degrees of freedom, confirmed the hypothesis of no serial correlation in errors up to lag 6 in all cases but burglaries. ${ }^{11}$ To correct for serial correlation, burglary equation is estimated using non-linear least squares with generalized sixth-order differencing.

All five crime categories are influenced by the number of police officers with short lags. For example, changes in the contemporaneous value and two past values of the police force (lags $=0-2$ ) influence the current rate of growth of robberies. Similarly, the growth rate of burglaries are influenced by current growth rate of the police force. With the exception of robberies, drug use also has a short-duration impact on crime. For example, the rate of change in murders at time $t$ is influenced only by the current rate of change in drug use. It is interesting to note that arrests have different lag structures between violent and non-violent crimes. For assaults, arrests have short-lived impacts: assaults are influenced by assault arrests three and four months ago, and murders are influenced by murder arrests of the third lag. Robberies, burglaries and motor vehicle thefts, on the other hand,

10 Although in all cases we had significance at the 5 percent level, the statistics for robbery, burglary and motor vehicle theft were not as high as assault and murder. Running robberry, burglary, and motor vehicle theft regressions withour incorporating cointegration did not change the results.

1 The critical value at the $10 \%$ level is 10.64. All test statistics are well below that number. 
present a longer dependence on arrests. Robberies are influenced by arrest that took place 3 to 11 months ago. The percentage change in motor vehicle thefts are influenced by percentage change in arrests that took place 3 to 13 months ago. Burglaries exhibit the longest dependence to arrests with 3 to 21 lags.

In Table 4, the first segment for each crime category presents the significant coefficients in the equation. For example, in the murder equation all of the coefficients of lagged murders ( $\alpha_{1}$ through $\left.\alpha_{7}\right)$ and the contemporaneous value of the AFDC cases $\left(\xi_{0}\right)$ are significantly different from zero. Because the explanatory variables generally enter with more than one lag, we calculated the sum of the estimated coefficients, which presents the long-run impact of the explanatory variables on the crime variable. $\Sigma \alpha$ stands for the sum of the lagged crime coefficients, $\Sigma \beta$ is the sum of the coefficients of drug use. $\Sigma \gamma, \Sigma \delta$ and $\Sigma \xi$ represent the sum of the coefficients of the number of police officers, the number of arrests, and the AFDC cases, respectively. As column I of Table 4 demonstrates, $\Sigma \beta$ for robberies is 0.380 . This means that a $10 \%$ increase in the rate of growth in drug use generates a $3.8 \%$ increase in the rate of growth of the number of robberies. $\Sigma \gamma$ is -0.998 for robberies, indicating that a $10 \%$ increase in the growth of the number of police officers brings about a $10 \%$ decrease in the growth rate of robberies. Similarly, the sum of the arrest coefficients $(\Sigma \delta)$ is negative for robberies, representing the inverse relationship between growth rates in robbery arrests and the number of robberies committed.

Similar relationships hold for Motor Vehicle Theft. There is a positive relationship between drug use and motor vehicle theft, although the magnitude is small. A $10 \%$ increase in the rate of growth of drug use brings about less than half a percentage point increase in motor vehicle theft. The sum of the coefficients of police and arrests are negative and significant. A 10 percent increase in the number of police officers generates a reduction of 8.3 percent and 10 percent increase in arrests brings about a 2.7 percent decrease in motor vehicle theft.

There is no impact of increased deterrence on burglary. The coefficient of police is not different from zero; so is the effect of the sum of lagged burglary arrests. The coefficients of drug use variables are positive and the one at lag three is significantly different from zero, indicating the positive relationship between growth in drug use and the 
growth in burglaries.

As for the violent crimes, we notice that an increase in the number of police officers constitutes a deterrence for assaults. A 10 percent increase in the growth rate of police officers causes a 9.5 percent decrease in assaults. In case of murders, we fail to detect any evidence on deterrence. Changes in the number of police officers and murder arrests are not associated with changes in the number of murders.

Assaults and murders are not related to changes in drug use. This result, which may be somewhat surprising, is consistent with the one reported by Corman, Joyce and Mocan (1991). Using an intervention analysis, they failed to document a structural upturn in the time-series behavior of murders in New York City around 1985. The results of this paper, in agreement with those of Corman, Joyce and Mocan (1991), present no evidence of a relationship between drug use and violent crimes such as murders and assaults at the aggregate level.

The growth in poverty, approximated by the rate of growth in the AFDC cases has a significant impact on murders. A 10 percent increase in the growth rate of the AFDC cases is associated with almost a 5 percent increase in the growth rate of murders. Changes in the number of AFDC cases have no impact on other types of criminal activity, with the possible exception of robberies, where the statistical significance is at the 11 percent level.

These results provide strong support for the deterrence hypothesis for robberies and motor vehicle theft. The evidence is weak in the case of burglaries and assaults, and there is no indication of a deterrence effect for murders. As Table 4 demonstrates, all crime variables have short dependence on police, but the lag lengths of arrests differ significantly. To investigate the sensitivity of the results to the variation in the lag length of arrests, we estimated the models by restricting the lag-length arrests to 3 through 9 for all five crime categories. The results, which are presented in column II of Table 4 , are in agreement with the ones reported in column I of the same Table.

\section{Discussion}

The purpose of this paper was to assess whether changes in drug use over time, as proxied by drug deaths, were related to changes in non-drug crime in New York City. By 
using recent time-series techniques, we were able to specify the crime supply function while circumventing many of the problems found in cross-sectional studies. In a multivariate analysis, after controlling for past values of crime, arrest rates, and size of the police force, and the number of AFDC cases, we find a positive and statistically significant effect of drug use on the three property-related crimes examined: robbery, burglary, and motor vehicle theft. An unexpected increase in drug usage has the largest and most long-lived effect on robberies--an elasticity of .38 with a 13-month effect. For both burglaries and auto thefts, the effect is short lived, and with an elasticity of about $0.03-0.04$. Thus, in the time-series sense, drug usage causes crime. That is, increases in drug deaths result in statistically significant increases in these three property-related crimes. Using the same techniques, we find no significant relationships between drug usage and violent crimes of felonious assault and murder. Increases in drug usage do not result in increases in these violent non-propertyrelated offenses, no matter what lag structure is specified. In this multivariate approach, we have controlled for the factors which may have an indirect effect on non-drug crime--arrest rates, size of the police force and the prevalence of poverty, proxied by the number of AFDC cases. We find that arrests deter crimes in the case of robberies and motor vehicle theft. In addition, police presence deters robberies, auto theft, and assaults. These finding support general deterrence hypothesis. We find no evidence of deterrence for murders.

During the time period studied, rates of imprisonment increased and average length of stay for the five crimes under analysis did not experience any decreases. ${ }^{12}$ Thus, we would not expect the deterrent effect on crime of police presence or arrests to decrease due to decreased expected punishments.

12 Source: New York State Department of Corrections, Public Information Office. 


\section{References}

Akaike, H, 1972, "Information Theory and the Extension of the Maximum Likelihood Principle," in B.N. Petrov and F. Csaki (eds.) Proceedings of the Second International Symposium on Information Theory, Budapest; pp. 267-81

Bachman, James E. and Witte, Ann D., "The Effectiveness of Legal Sanctions on Individuals Addicted to Alcohol or Drugs," in Leveson, Irving, ed., Quantitative Explorations in Drug Abuse Policy, Spectrum Publications: N.Y. $1980,111-127$

Becker, Gary, "Crime and Punishment: An Economic Approach," Lournal of Political Economy, 1968, 76:169-217.

Becker, Gary, Michael Grossman and Kevin M. Murphy, "Rational Addiction and the Effect of Price on Consumption," The American Economic Review Papers and Proceedings, May, 1991, 237-241.

Benson, Bruce L., Iljoong Kim, David W. Rasmussen, Thomas W. Zuehlke. "Is Property Crime Caused By Drug Use Or By Drug Enforcement Policy." Applied Economics, Vol 24, 1992: pp. 679-692.

Benson, Bruce L., Ijoong Kim, David W. Rasmussen. "Estimating Deterrence Effects: A Public Choice Perspective on the Economics of Crime Literature," Southern Economic Joumal, Vol 61, No 1, July 1994: pp 161-168.

Benson, Bruce L. and David W. Rasmussen. "Relationship Between Mlicit Drug Enforcement Policy and Property Crimes," Contemporary Policy Issues, Vol 9, No 4, Oct 1991: pp 106-15.

Blackburn Keith and Morton O. Ravn, "Business Cycles in the United Kingdom: Facts and Fictions," Economica, 1992. 59:383-401.

Block, M. and M. Heineke, : A Labor Theoretic Analysis of the Criminal Choice," The American Economic Review, 1975, 314-25.

Chaiken, Jan M. and Marcia R. Chaiken. "Drugs and Predatory Crime," in Tonry, Michael, and James Q. Wilson, eds., Drugs and Crime, Vol 13, Chicago: University of Chicago Press, 1990: pp 203-239.

Chiricos, T. "Rates of Crime and Unemployment: An Analysis of Aggregate Research Evidence," Social Problems, 1987, 34:187-203.

Corman, Hope, Joyce, Theodore and Mocan, Naci, "Homicides and Crack in New York City," in Lazear, Edward and Krauss, Melvyn, eds., Drug Policy in the United States, 1991, Stanford, Califormia: Hoover Institution Press.

Cornwell, Christopher and Trumbull, William N.,"Estimating the Economic Model of Crime with Panel Data," Review of Economics and Statistics, Vol. 76, May 1994: pp. 360-366.

Cover, James Perry, and Paul Thistle, "Time Series, Homicide, and the Deterrent Effect of Capital Punishment," Southern Economic Joumal, January 1988, V54,615-622

Craig, Steven G, "The Deterrent Impact of Police: An Examination of a Locally Provided Public Service," Joumal of Urban Economics, 1987, 21: 298-311.

Dickey, D.A. and W.A. and Fuller, "Likelihood Ratio Statistics for Autoregressive 
Time Series with a Unit Root," Econometrica, 1981, 49:1057-72.

Ehrlich, Isaac. "Participation in Illegitimate Activities: A Theoretical and Empirical Investigation," Joumal of Political Economy, 1973, V81, 521-565.

Ehrlich, Isaac. "The Deterrent Effect of Capital Punishment: A Question of Life and Death," American Economic Review, 1975, V65, 397-417.

Engle Robert F. and Clive W.J. Granger, "Introduction," in Engle R.F. and Clive W.J. Granger (eds.) Long-run Economic Relationships, Oxford University Press: New York, 1991; pp. 1-16.

Fisher, Franklin, and Nagin, Daniel, "On the Feasibility of Identifying the Crime Function in a Simultaneous Model of Crime Rates and Sanction Levels," in Blumstein, Alfred, et al. (eds.), Deterrence and Incapacitation: Estimating the Effects of Criminal Sanctions on Crime Rates, Washington, D.C.; National Academy of Sciences, 1978, 361-400.

Freeman, R. "Crime and Unemployment," in Wilson, James Q., (ed.), Crime and Public Policy, San Francisco:ICS Press, 1983, 89-106.

Fuller, W., Introduction to Statistical Time Series, Wiley: New York, 1976.

Furlong, William J., and Stephen L. Mehay, "Urban Law Enforcement in Canada: An Empirical Analysis," Canadian Journal of Economics, 1981, V14, 44-57. Galvin, Jim, "Rape: A Decade of Reform,". Crime and Delinquency, Vol 31, No 2, April 1985: pp. 163-168.

Gandossy, Robert P., et. al," Drugs and Crime: A Survey and Analysis of the Literature," U.S. Dept. of Justice. National Institute Justice:Washington. D.C. 1980.

Goldstein, Paul, "The Drugs/Violence Nexus: A Tripartite Conceptual Framework," Joumal of Drug Issues, 1985, 15:493-506.

Goldstein, Paul J., Bellucci, Patricia A., Spunt, Barry J., and Miller, Thomas. "Volume of Cocaine Use and Violence: A Comparison Between Men and Women," Journal of Drug Issues, Vol 21, No 2, Spring 1991: pp. 345-367.

Granger, Clive W.J. and Paul Newbold, "Spurious Regressions in Econometrics," Joumal of Economics, 1974, pp. 111-20.

Granger, Clive W. J. Forecasting in Business and Economics, 1989, San Diego: Academic Press, 2nd Edition.

Grogger, Jeffrey, "Certainty vs. Severity of Punishment, " Economic Inquiry, 1991, XXIX:2, pp. 297-309.

Gropper, Bernard," Probing the Links Between Drugs and Crime,", National Institute of Justice, Research in Brief, U.S. Dept of Justice National Institute of Justice, Feb 1985.

Harrison, Lana D. "The Drug-Crime Nexus in the USA," Contemporary Drug Problems, Vol 19, No.2, Summer 1992: pp. 203-246.

Hodrick R. and E.C. Prescott, "Postwar U.S. Business Cycles: An Empirical Investigation," 1980. Mimeo, Camegie-Mellon University.

Johnson, Bruce D. and John Muffler. 1992. "Sociocultural Aspects of Drug Use and 
Abuse in the 1990's," Pp 118-37 in Joyce Lowinson, Pedro Ruiz and Ronald Millman, eds. Substance Abuse Treatment. Baltimore: Wilkins and Wilkins. Second Edition.

Kim, Iljoong; Benson, Bruce L.; Rasmussen, David W. "An Economic Analysis of Recidivism Among Drug Offenders," Southem Economic Joumal, Vol 60, July 1993: pp 169-83.

Kleiman, Mark, "Crackdowns: The Effects of Intensive Enforcement on Retail Heroin Dealing," in Chaiken, Marcia, ed., Street-Level Drug Enforcement: Examining the Issues, September, 1988, Washington, DC: National Institute of Justice, 3-34.

Kleiman, Mark and Smith, Kerry," State and Local Drug Enforcement: In Search of a Strategy," in Tonry, Michael and Wilson, James Q., eds.,Drugs and Crime , 1990, Chicago:University of Chicago Press, pp: 69-108.

Layson, Stephen K., "Homicide and Deterrence: A Reexamination of the United States Time-Series Evidence," Southem Economic Joumal, 1985, 52:1, pp. 68-89.

Long, Sharon and Witte, Ann, "Current Economic Trends: Implications for Crime and Criminal Justice," in Wright, Kevin, ed., Crime and Criminal Justice in a Declining Society, Gunn and Hain: Cambridge, MA, 1981, 69-143.

MacKinnon, James, "Critical Values for Cointegration Tests," in Engle R.F. and Clive W.J. Granger (eds.) Long-run Economic Relationships, Oxford University Press: New York, 1991; pp. 1-16.

Mathur, Vijay K., "Economics of Crime: An Investigation of the Deterrent Hypothesis for Urban Areas," The Review of Economics and Statistics, 1978, V60, 459-466.

McBride, Duane C., "Drugs and Violence," in Inciardi, James, ed.,The DrugsCrime Connection. Beverly Hills: Sage, 1981, 105-124.

Mocan, Naci. "Is there a Unit-Root in U.S. Real GNP? A Re-Assessment," Economics Letters, 1994, 45: 23-31.

Moore, Mark, "Supply Reduction and Drug Law Enforcement," in Tonry, Michael and Wilson, James Q., eds., Drugs and Crime, Vol 13, Chicago: University of Chicago Press, 1990: pp 109-158.

Moore, Mark and Kleiman, Mark, The Police and Drugs, September, 1989, Washington, DC: National Institute of Justice.

Myers, Samuel L. Jr., "Crime in Urban Areas: New Evidence and Results." Journal of Urban Economics, 1982, 148-158.

Myers, Samuel L. Jr., "Estimating the Economic Model of Crime: Employment Versus Punishment Effects," Quarterly Joumal of Economics, 1983, 157-166.

Nagin, Daniel, "General Deterrence: A Review of the Empirical Evidence," in Blumstein, Alfred, et al. (eds.), Deterrence and Incapacitation: Estimating the Effects of Criminal Sanctions on Crime Rates, Washington, D.C.; National Academy of Sciences, 1978.

Nelson, C.R., and H. Kang, "Pitfalls in the Use of Time as an Explanatory Variable 
in Regression," Journal of Business and Economic Statistics, 1984, 2:73-82.

Nelson, C.R., and H. Kang, "Spurious Periodicity in Inappropriately Detrended Time Series," Econometrica, 1981, 49:741-51.

Phillips, Llad and Harold Votey, "Crime Control in California," Journal of Legal, Studies, 1975, 327-49.

Rasmussen, David W. and Benson, Bruce L. "The Economic Anatomy of a Drug War," Rowman \& Littlefield Publishers, Inc., 1994.

Reuter, Peter and Kleiman, Mark, "Risks and Prices: An Economic Analysis of Drug Enforcement," in Tonry, Michael and Morris, Norval, eds., Crime and Justice: An Annual Review of Research, 1986, Chicago: University of Chicago Press.

Rottenberg, Simon, "The Clandestine Distribution of Heroin, Its Discovery and Suppression," Joumal of Political Economy, January, 1968, 76:78-90.

Saffer, Henry and Frank Chaloupka, "The Demand for Illicit Drugs." National Bureau of Economic Research Working Paper. No. 5238, August 1995.

Schmidt, Peter and Ann Dryden Witte, An Economic Analysis of Crime and Justice: Theory. Methods and Applications, 1984, Orlando, Florida: Academic Press.

Silverman, Lester P. and Nancy Spruill, "Urban Crime and the Price of Heroin," Joumal of Urban Economics, 1977, 4:80-103.

Sjoquist, David Lawrence, "Property, Crime and Economic Behavior: Some Empirical Results," The American Economic Review, June 1973, 439-446.

Sollars, David L., Bruce L. Benson, David Rasmussen. "Drug Enforcement and the Deterrence of Property Crime Among Local Jurisdictions, " Public Finance Quarterly, Vol 22, No 1, January 1994: pp. 22-45.

Speckart, George and H. Douglas Anglin, "Narcotics Use and Crime: An Overview of Recent Research Advances," Contemporary Drug Problems, 1986, 13:741769.

Stock, J. H and Watson M.W. "Variable Trends in Economic Time Series," Joumal of Economic Perspectives, 1988, 2: 147-74.

Wish, Eric and Johnson, Bruce," The Impact of Substance Abuse on Criminal Careers," in Blumstein, Alfred, et. al. (eds.) ,Criminal Careers and Career Criminals, Vol. 2, National Academy Press: Washington DC, 1986, 52-88.

Witte, Ann Dryden, "Estimating the Economic Model for Crime with Individual Data." Quarterly Joumal of Economics, February 1980, 57-84.

White, Michael D. and Luksetich, William A., "Heroin: Price Elasticity and Enforcement Strategies," Economic Inquiry, October, 1983, 31:557-564. 
Table 1 Means of Variabies

VARIABLE

DRUG USAGE

Drug Deaths

POLICE

Total number of officers

26559

NON-DRUG ARRESTS

Murder Arrest Rate

Assault Arrest Rate

Robbery Arrest Rate

Burglary Arrest Rate

Auto Theft Arrest Rate

Total Number of Arrests: Murder, Assault, Robbery, Burglary, Rape, Auto Theft, and Grand Larceny

NON-DRUG CRDMES

Murder

Robbery

7061

Assault

2523

Burglary

13224

Auto Theft

8036 
Table 2

Unit Root Tests

\begin{tabular}{|c|c|c|c|}
\hline Variable & $\begin{array}{c}\text { Without } \\
\text { Constant }\end{array}$ & $\begin{array}{c}\text { With } \\
\text { Constant }\end{array}$ & $\begin{array}{c}\text { With } \\
\text { Trend }\end{array}$ \\
\hline Robbery & 0.070 & -2.115 & -2.640 \\
\hline Burglary & -1.092 & -1.027 & -1.741 \\
\hline $\begin{array}{c}\text { Motor Vehicle } \\
\text { Theft }\end{array}$ & 0.243 & -1.316 & -2.791 \\
\hline $\begin{array}{c}\text { Assault } \\
\text { Murder }\end{array}$ & $3.156^{\circ}$ & -1.404 & -1.337 \\
\hline $\begin{array}{c}\text { Robbery } \\
\text { Arrests }\end{array}$ & 1.465 & -2.064 & -2.155 \\
\hline $\begin{array}{c}\text { Burglary } \\
\text { Arrests }\end{array}$ & -0.641 & -1.971 & -3.398 \\
\hline $\begin{array}{c}\text { Motor Vehicle } \\
\text { Theft Arrests }\end{array}$ & 0.646 & -0.207 & -2.497 \\
\hline $\begin{array}{c}\text { Assault } \\
\text { Arrests }\end{array}$ & 1.832 & -1.850 & -1.887 \\
\hline $\begin{array}{c}\text { Murder } \\
\text { Arrests }\end{array}$ & 0.624 & -2.313 & -1.949 \\
\hline $\begin{array}{c}\text { AFDC Cases } \\
\text { MFin }\end{array}$ & 0.224 & $-2.995 *$ & -2.727 \\
\hline
\end{tabular}

- Significant at $5 \%$

5\% Critical Values: Without Constant: -1.941 , With Constant: -2.873 , With Trend: -3.428 
Table 3

Cointegration Test Statistics

\begin{tabular}{|c|c|c|}
\hline Variable & Specification & t-value \\
\hline \multirow[t]{2}{*}{ Robbery } & Constant & $-4.99^{\circ}$ \\
\hline & $\begin{array}{l}\text { Constant \& } \\
\text { Trend }\end{array}$ & $-4.08^{\circ}$ \\
\hline \multirow[t]{2}{*}{ Burglary } & Constant & $-4.49^{\circ}$ \\
\hline & $\begin{array}{c}\text { Constant \& } \\
\text { Trend }\end{array}$ & $-4.48^{\circ}$ \\
\hline \multirow{2}{*}{$\begin{array}{l}\text { Motor Vehicle } \\
\text { Theft } \\
\end{array}$} & Constant & $-4.56^{\circ}$ \\
\hline & $\begin{array}{c}\text { Constant \& } \\
\text { Trend }\end{array}$ & $-4.55^{\circ}$ \\
\hline \multirow[t]{2}{*}{ Assault } & Constant & $-6.46^{\circ}$ \\
\hline & $\begin{array}{c}\text { Constant \& } \\
\text { Trend }\end{array}$ & $-6.44^{\circ}$ \\
\hline \multirow[t]{2}{*}{ Murder } & Constant & $-11.58^{\circ}$ \\
\hline & $\begin{array}{l}\text { Constant \& } \\
\text { Trend }\end{array}$ & $-11.55^{\circ}$ \\
\hline
\end{tabular}

*-Significant at $5 \%$ 
Table 4

Summary of Regression Results

\begin{tabular}{|c|c|c|}
\hline Murder & 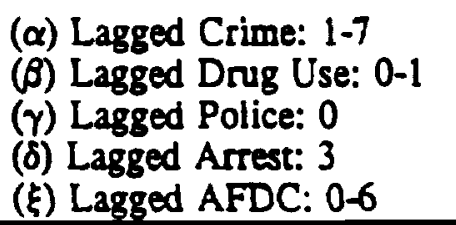 & 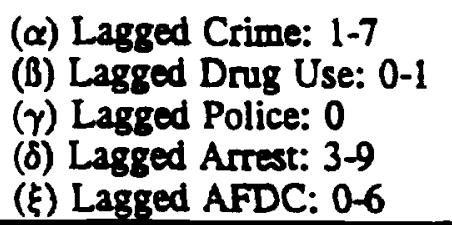 \\
\hline & 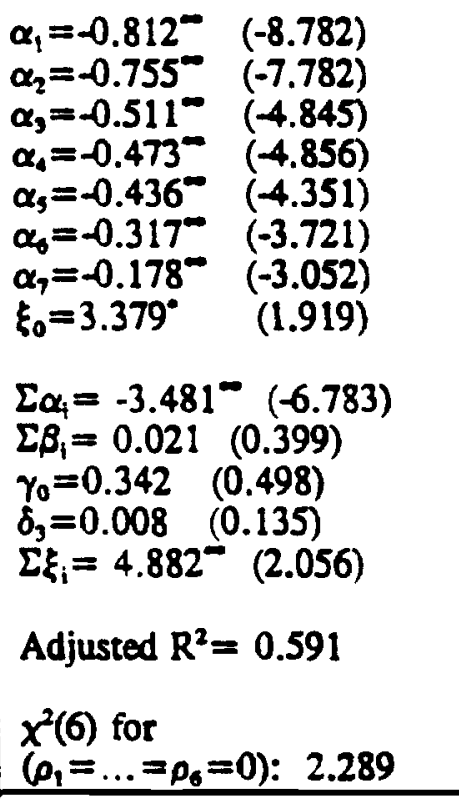 & 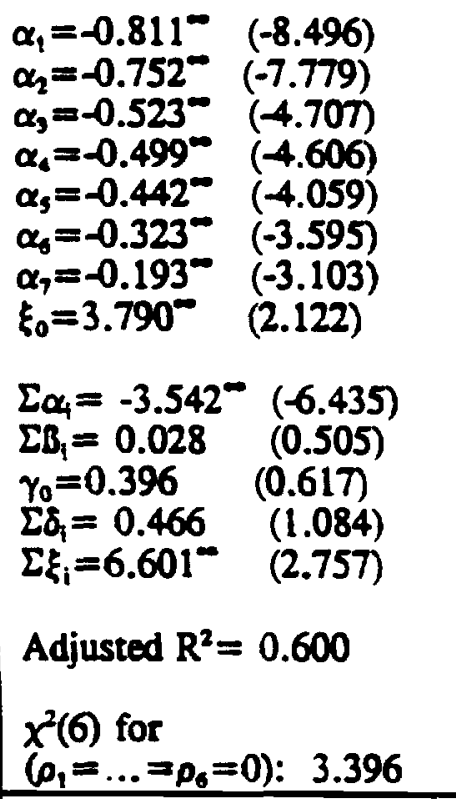 \\
\hline Assault & $\begin{array}{l}(\alpha) \text { Lagged Crime: } 1-6 \\
(\beta) \text { Lagged Drug Use: } 0-3 \\
(\gamma) \text { Lagged Police: } 0-3 \\
(\delta) \text { Lagged Arrest: } 3-4 \\
(\xi) \text { Lagged AFDC: } 0-1\end{array}$ & 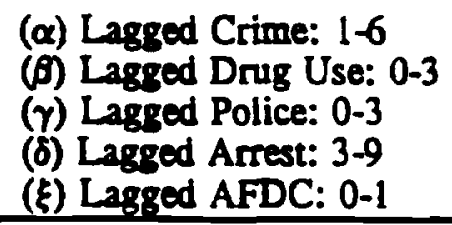 \\
\hline & $\begin{array}{ll}\alpha_{1}=-0.468^{-} & (-7.179) \\
\alpha_{2}=-0.341^{-} & (-4.761) \\
\alpha_{3}=-0.303^{-} & (-3.487) \\
\alpha_{1}=-0.287^{-} & (-3.432) \\
\alpha_{5}=-0.244^{-} & (-3.850) \\
\alpha_{6}=-0.178^{-} & (-2.528) \\
& \\
\Sigma \alpha_{4}=-1.821^{-} & (-6.683) \\
\Sigma \beta_{1}=-0.004 & (-0.104) \\
\Sigma \gamma_{i}=-0.945^{\circ} & (-1.945) \\
\Sigma \alpha_{1}=0.076 & (0.491) \\
\Sigma \xi_{1}=0.986 & (0.948) \\
& \\
\text { Adjusted } R^{2}=0.717 \\
\chi^{2}(0) \text { for } \\
\left.\sigma_{1}=\ldots=p_{6}=0\right): 6.011\end{array}$ & 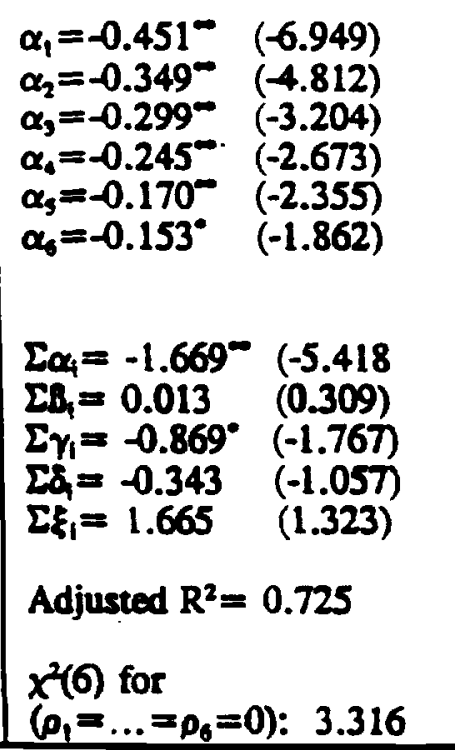 \\
\hline
\end{tabular}


(Table 4 continued)

\begin{tabular}{|c|c|c|}
\hline Robbery & 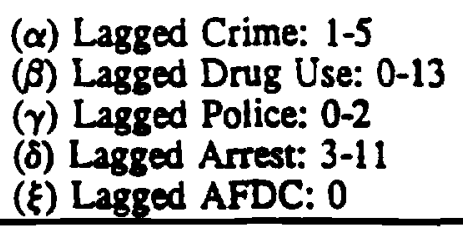 & 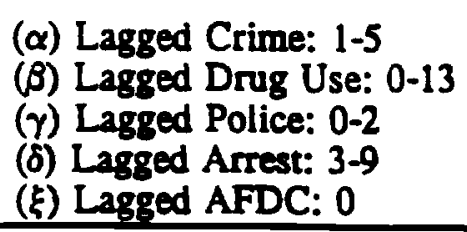 \\
\hline & 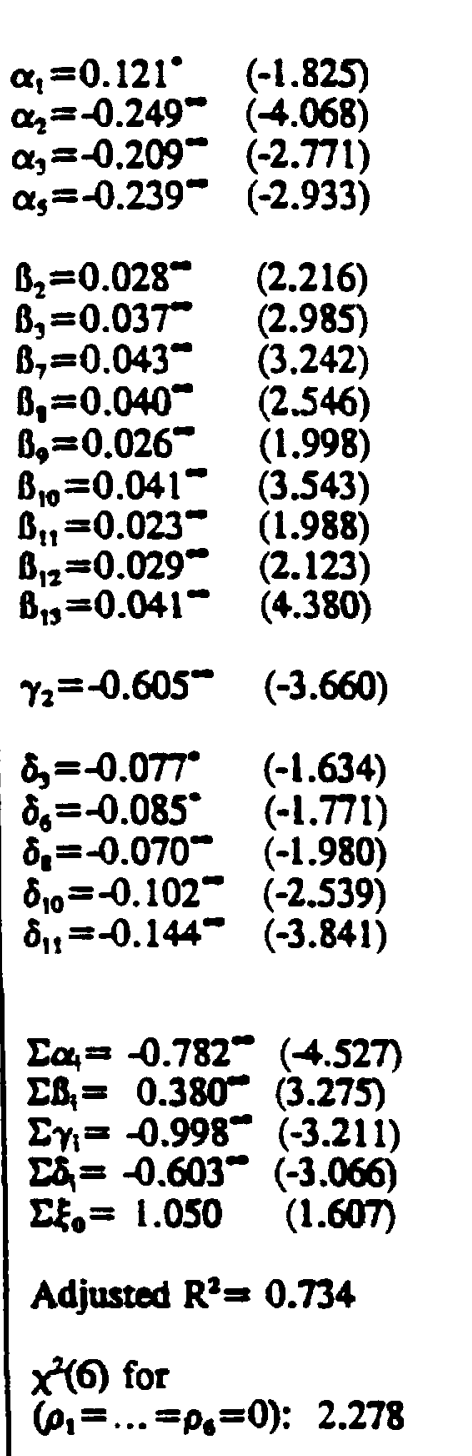 & 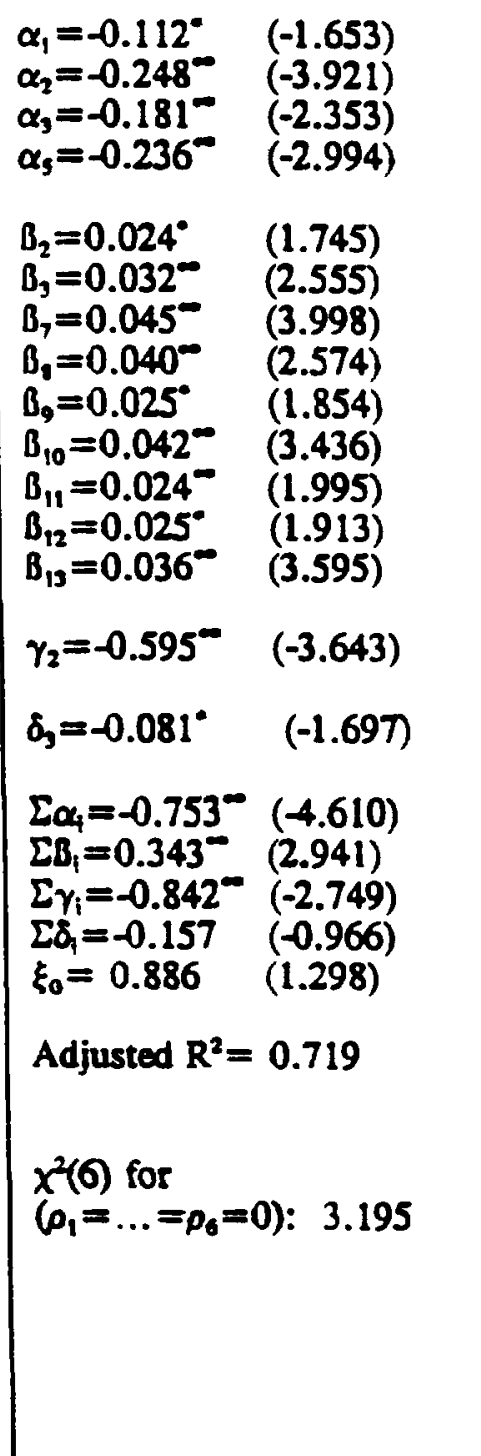 \\
\hline
\end{tabular}


(Table 4 concluded)

\begin{tabular}{|c|c|c|}
\hline Burglary & $\begin{array}{l}\text { ( } \alpha) \text { Lagged Crime: } 1-12 \\
(\beta) \text { Lagged Drug Use: } 0-3 \\
(\gamma) \text { Lagged Police:0 } \\
(\delta) \text { Lagged Arrest: } 3-21 \\
(\xi) \text { Lagged AFDC: } 0-6\end{array}$ & $\begin{array}{l}(\alpha) \text { Lagged Crime: } 1-12 \\
(\beta) \text { Lagged Drug Use: } 0-3 \\
(\gamma) \text { Lagged Police:0 } \\
(\delta) \text { Lagged Arrest: } 3-9 \\
(\xi) \text { Lagged AFDC: } 0-6\end{array}$ \\
\hline & $\begin{array}{ll}\alpha_{2}=-0.427^{-} & (-3.725) \\
\alpha_{1}=-0.430^{-} & (-3.808) \\
\alpha_{3}=0.291^{-} & (2.365) \\
\alpha_{1}=0.401^{-} & (3.524) \\
\alpha_{9}=0.368^{-} & (3.534) \\
\alpha_{10}=0.304^{-} & (2.905) \\
\alpha_{12}=0.306^{-} & (3.060) \\
\beta_{3}=0.033^{-} & (2.893) \\
\delta_{1}=-0.096^{\circ} & (-1.868) \\
\delta_{1}=-0.161^{-} & (-2.696) \\
\delta_{13}=0.123^{-} & (2.218) \\
\delta_{16}=0.103^{\circ} & (1.954) \\
\xi_{2}=1.429^{\circ} & (2.155) \\
\xi_{3}=-1.216^{\circ} & (-1.778) \\
& \\
\Sigma \alpha_{4}=1.104 & (0.139) \\
\Sigma \beta_{1}=0.056 & (0.189) \\
\gamma_{0}=-0.233 & (-1.432) \\
\Sigma \delta_{1}=-0.170 & (-0.023) \\
\Sigma \xi_{i}=-0.858 & (-0.030) \\
x^{2}(6) \text { for } & \\
\left(\rho_{1}=\ldots=p_{6}=0\right): 1.619\end{array}$ & $\begin{array}{ll}\alpha_{2}=-0.527^{-} & (-4.152) \\
\alpha_{1}=-0.513^{-} & (-3.406) \\
\alpha_{3}=0.436^{\circ} & (2.365) \\
\alpha_{1}=0.348^{\circ} & (2.261) \\
\alpha_{9}=0.402^{-} & (3.274) \\
\alpha_{12}=0.372^{-} & (4.130) \\
B_{3}=0.022^{\circ} & (2.120) \\
\xi_{2}=1.775 & (2.705) \\
\xi_{3}=-1.477^{-} & (-2.040) \\
& \\
& \\
\Sigma \alpha_{1}=0.968 & (0.158) \\
\Sigma \beta_{1}=0.061 & (0.207) \\
\gamma_{0}=-0.110 & (-0.753) \\
\Sigma \delta_{1}=-0.125 & (-0.029) \\
\Sigma \xi_{1}=-0.208 & (-0.011) \\
& \\
\chi^{2}(6) \text { for } & \\
\left.\omega_{1}=\ldots=p_{0}=0\right):\end{array}$ \\
\hline Motor Vehicle Theft & $\begin{array}{l}(\alpha) \text { Lagged Crime: } 1 \\
(\beta) \text { Lagged Drug Use: } 0-1 \\
(\gamma) \text { Lagged Police: } 0-2 \\
(\delta) \text { Lagged Arrest: } 3-13 \\
(\xi) \text { Lagged AFDC: } 0\end{array}$ & 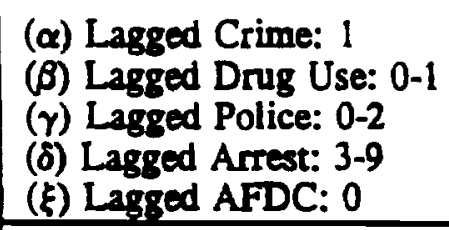 \\
\hline & 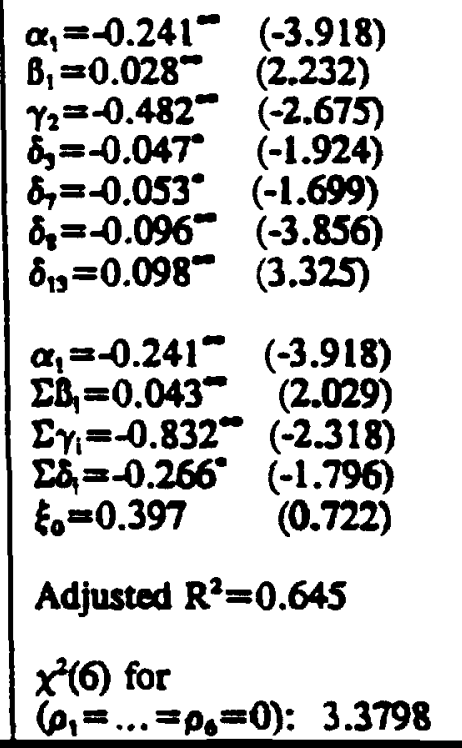 & 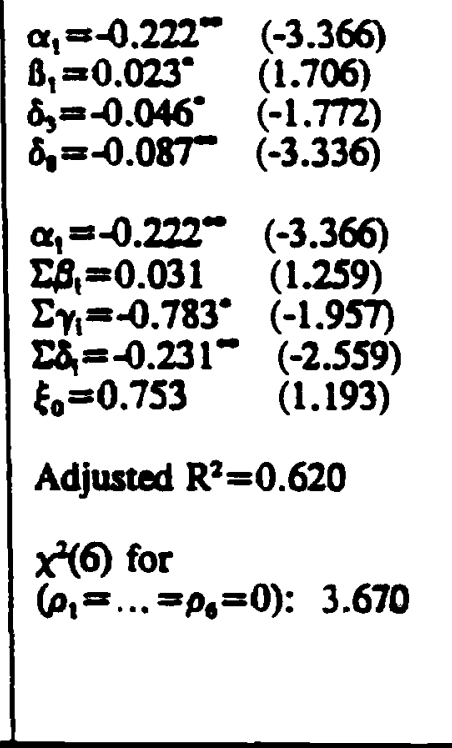 \\
\hline
\end{tabular}




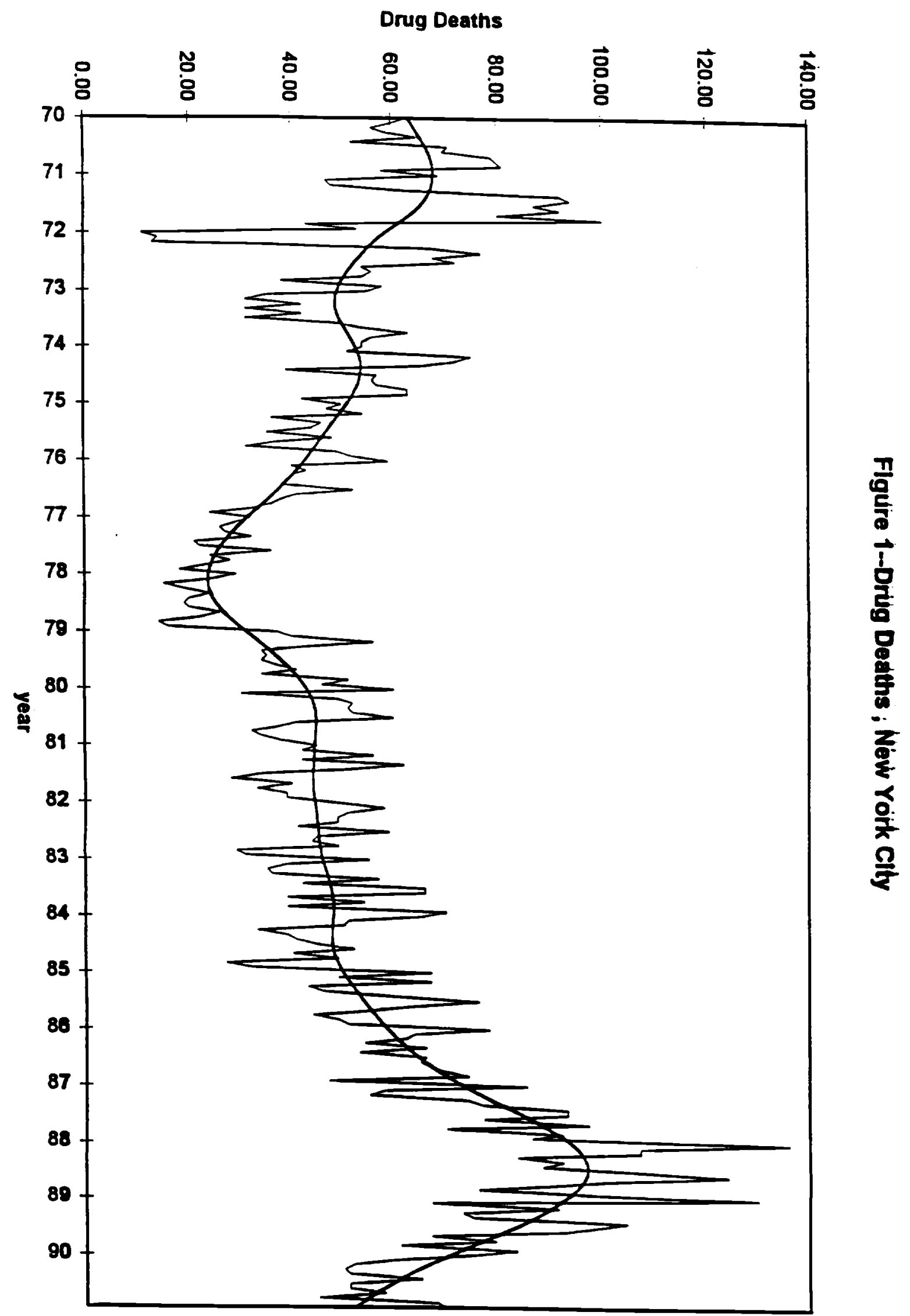


Figure 2--Pollet Ofiicers, New Ybik City

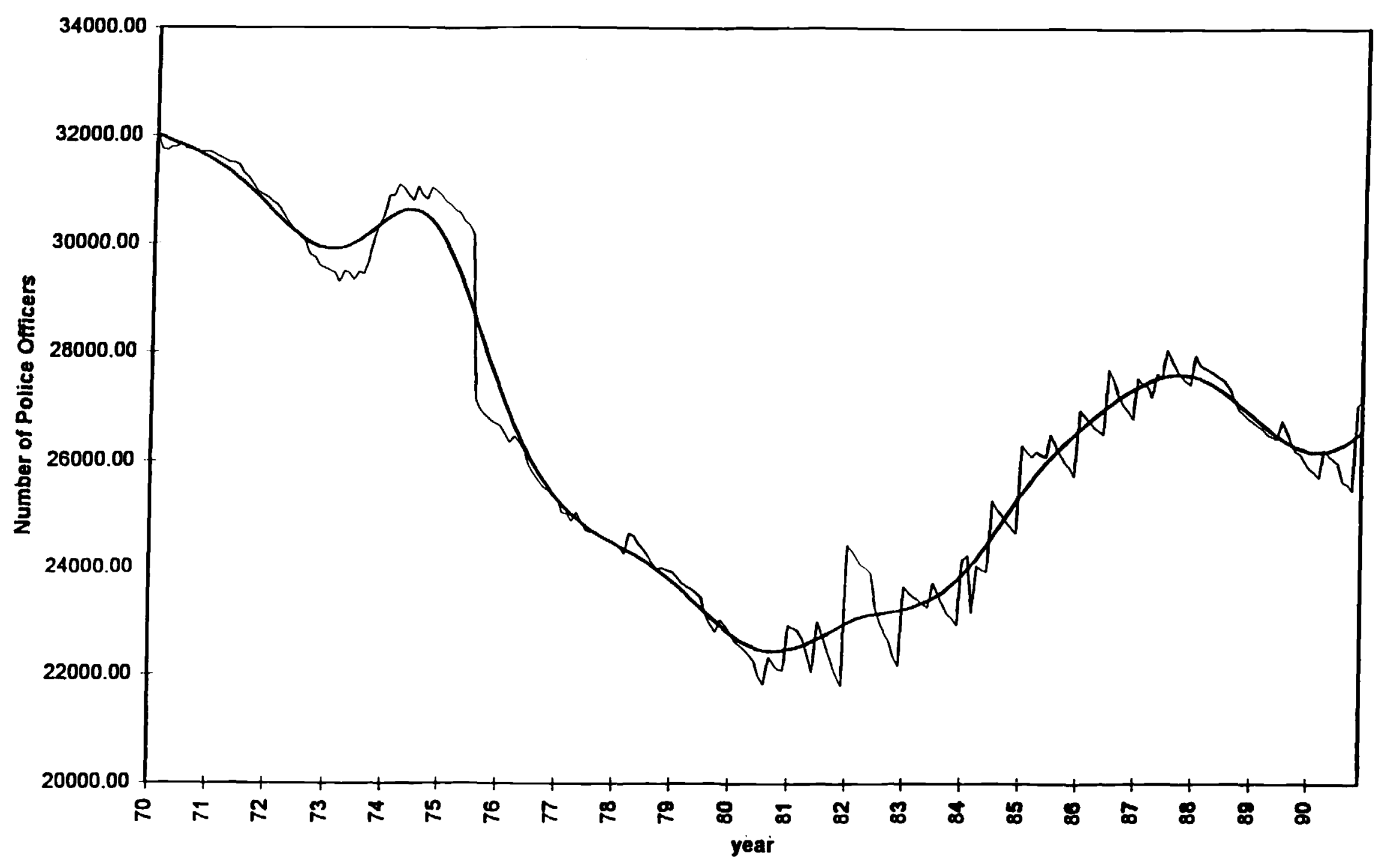


Flgutrë 3-Mutrder Atrest Ràtë

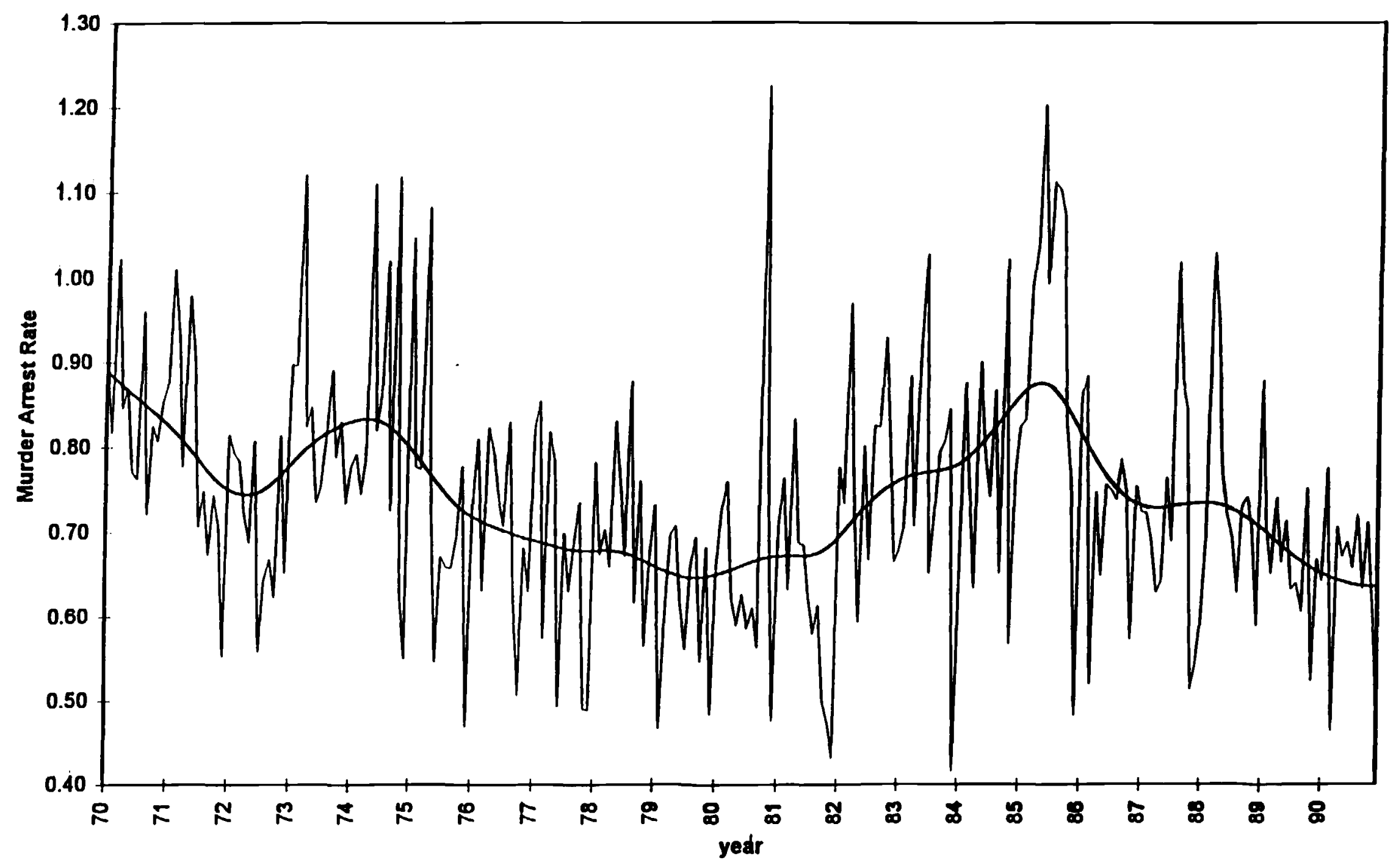




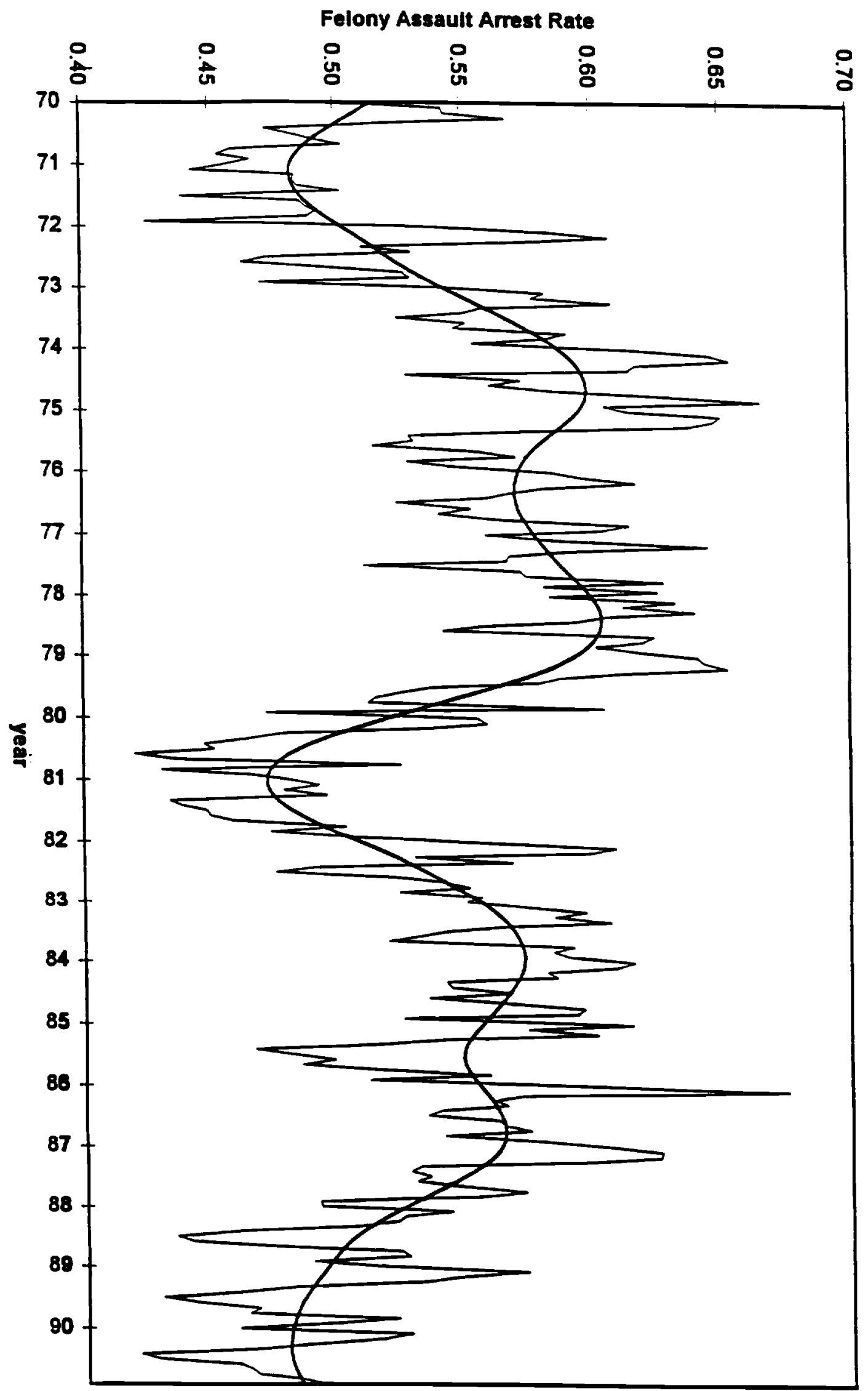

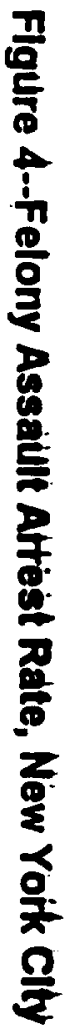


Figure 5--Robbety Arrest Ratë, New York City

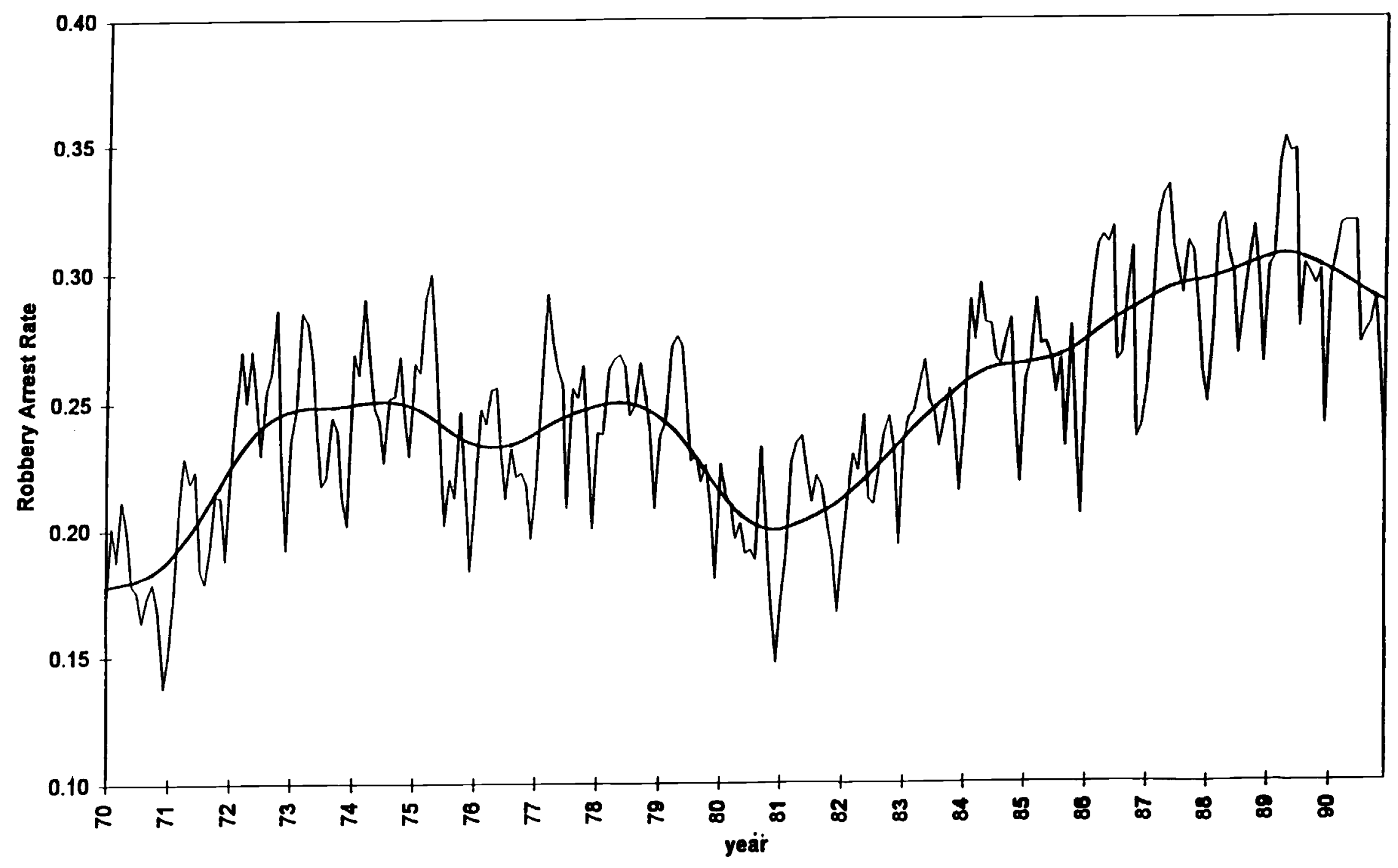




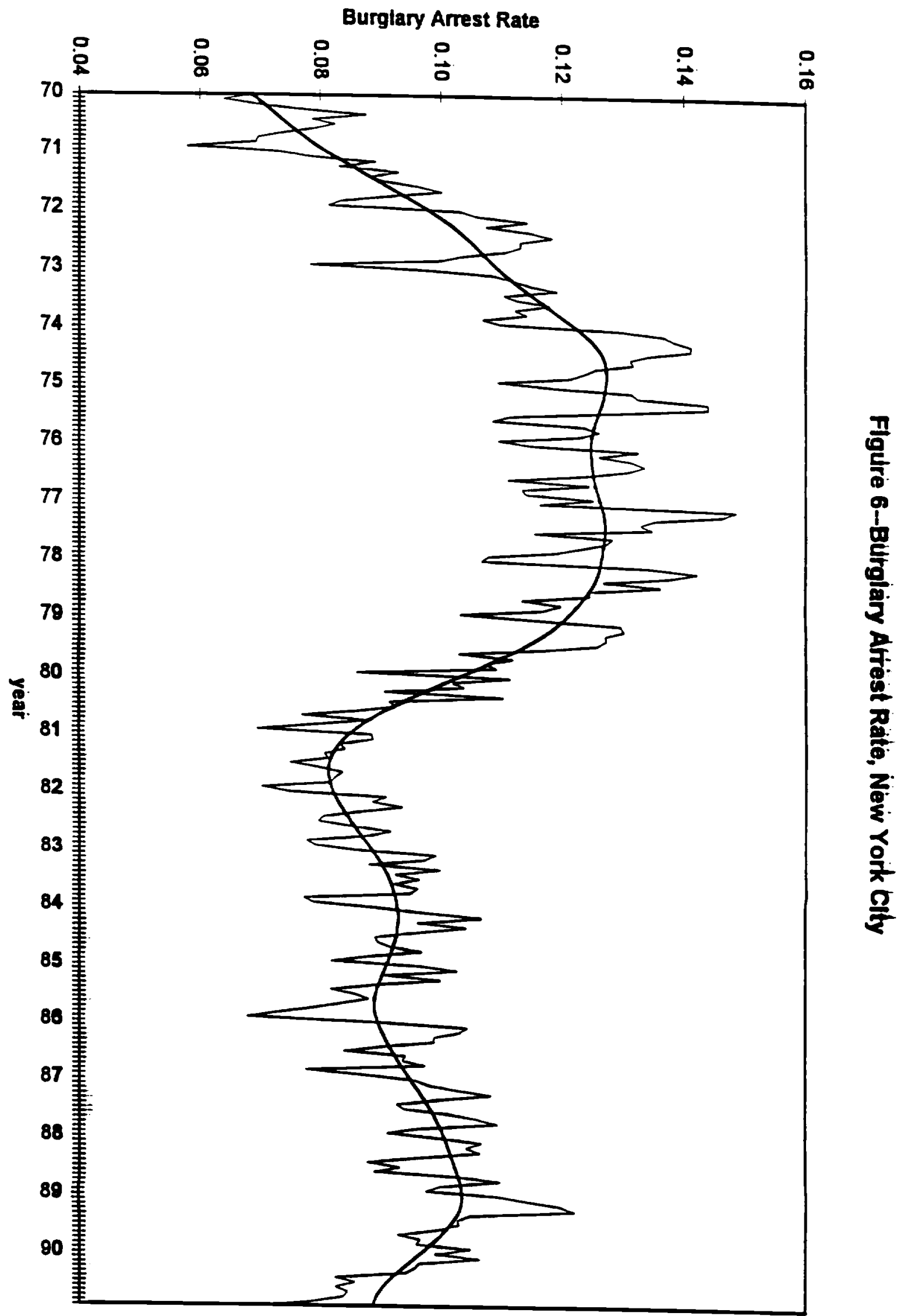


Figure 7--Motor Vehlcld Thefit Arrest Rattè

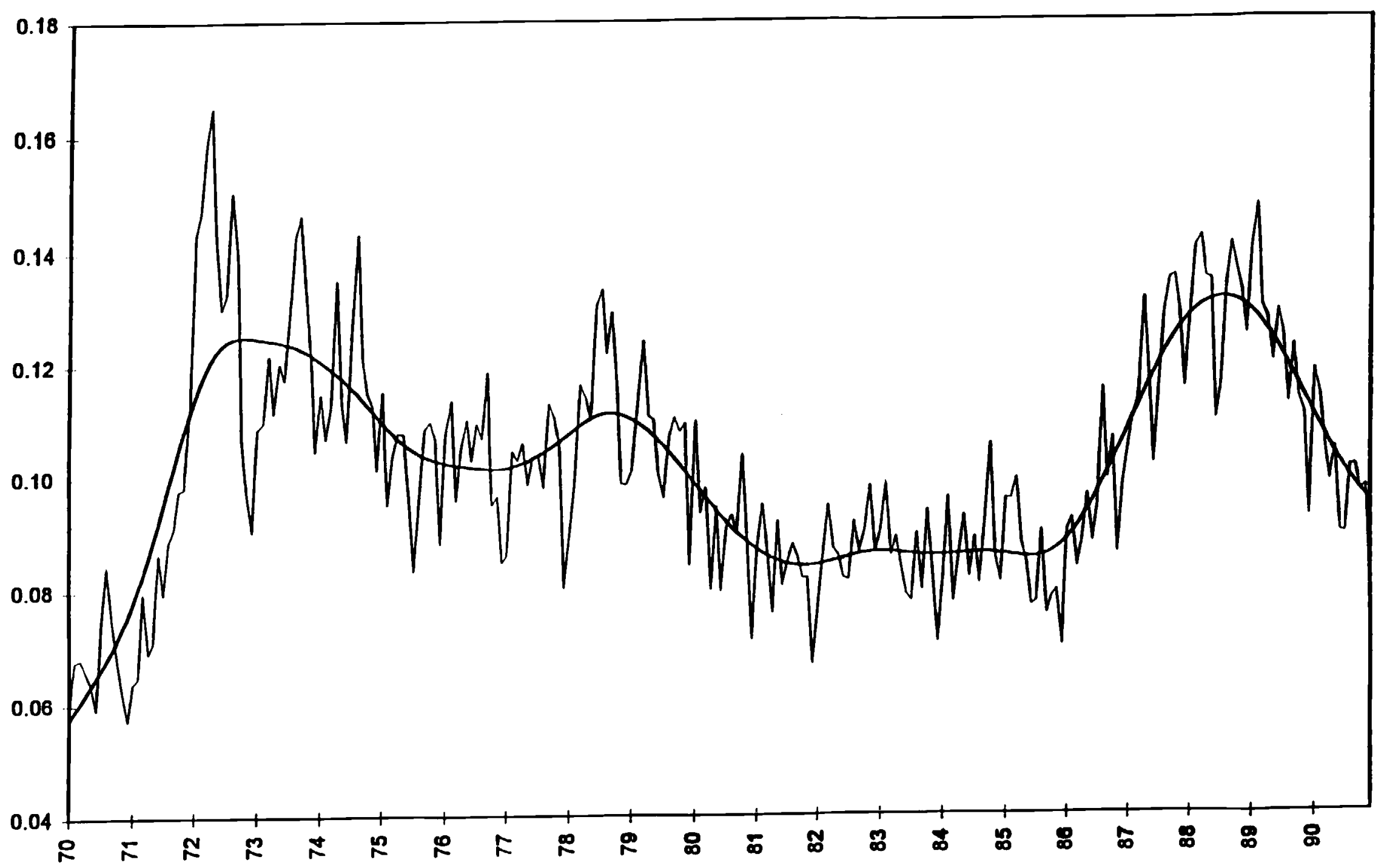




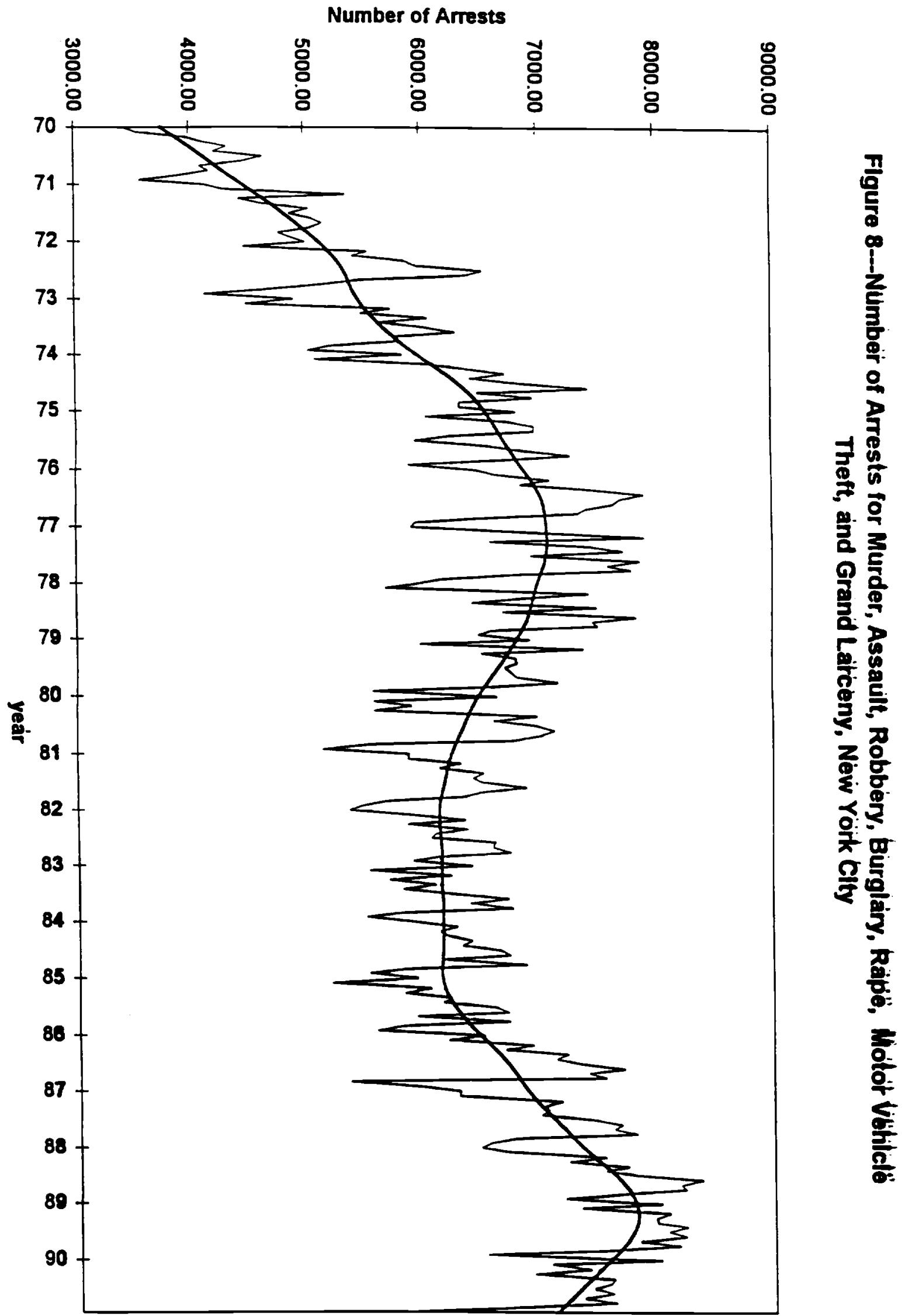




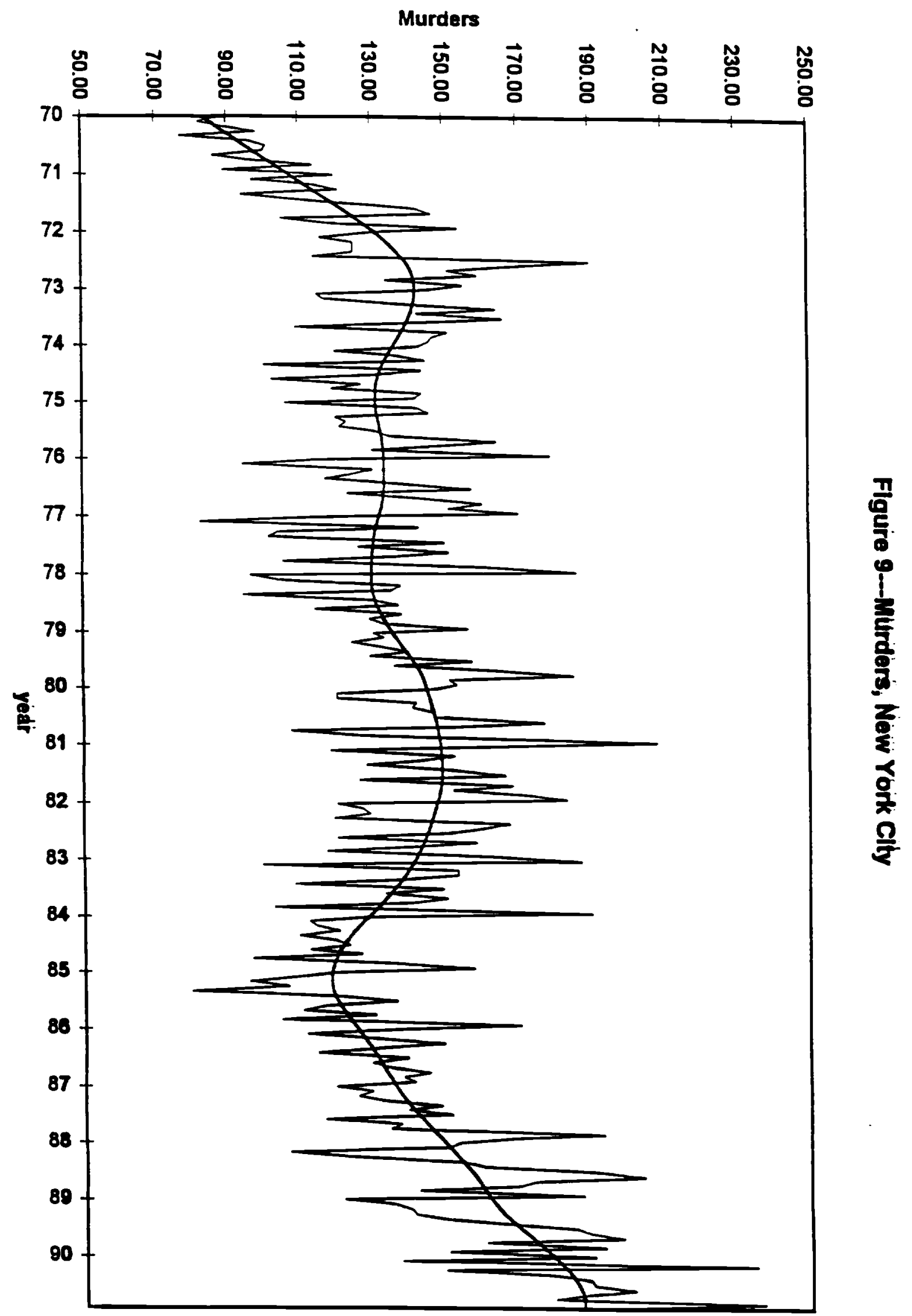


Figure 10-Felony Assadutts, New Yoik Clty

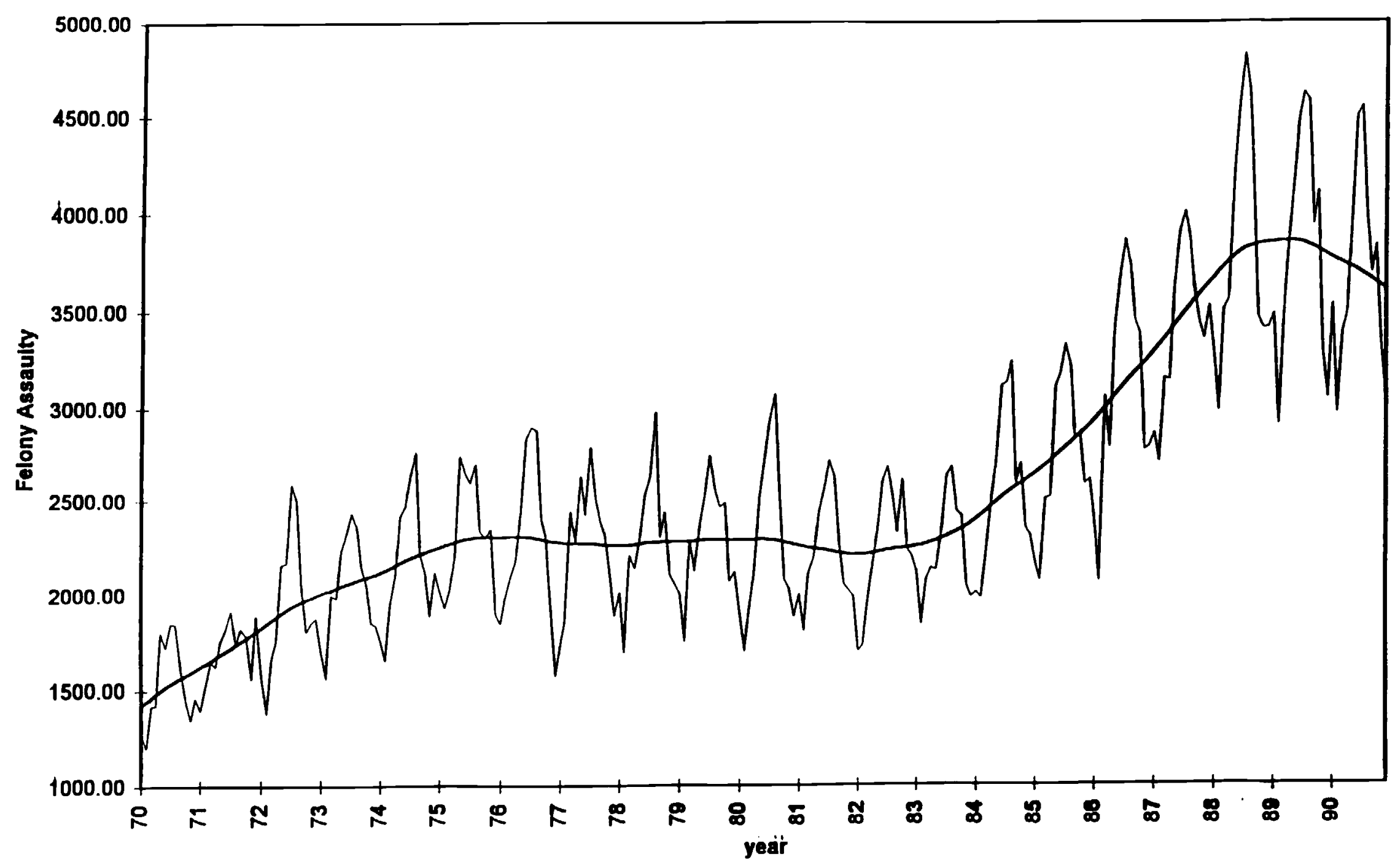


Figurë 11--Robbetlbs, Neẅ Yotk City

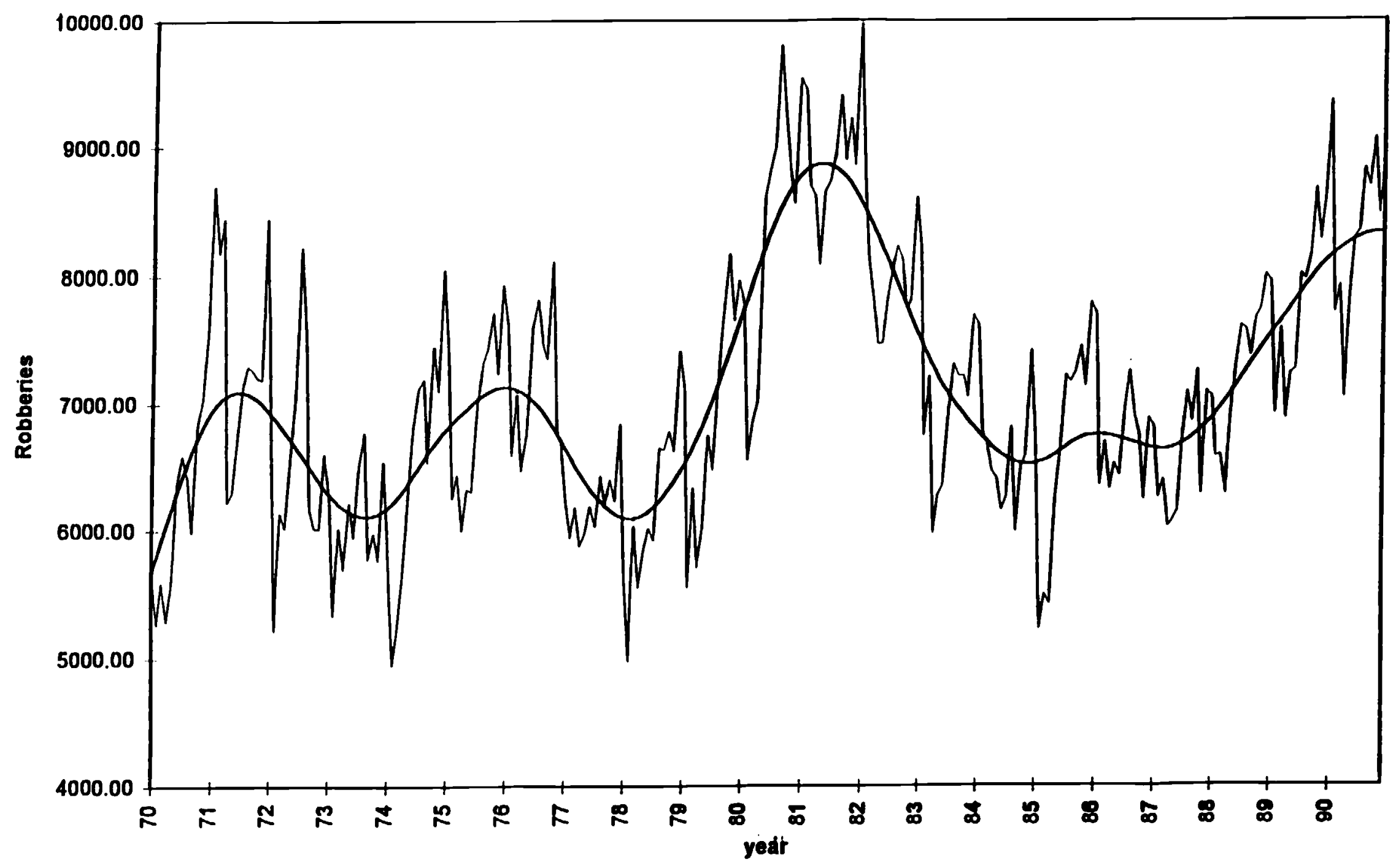


Figuire 12--Butglatles, Něw Yoik Clty

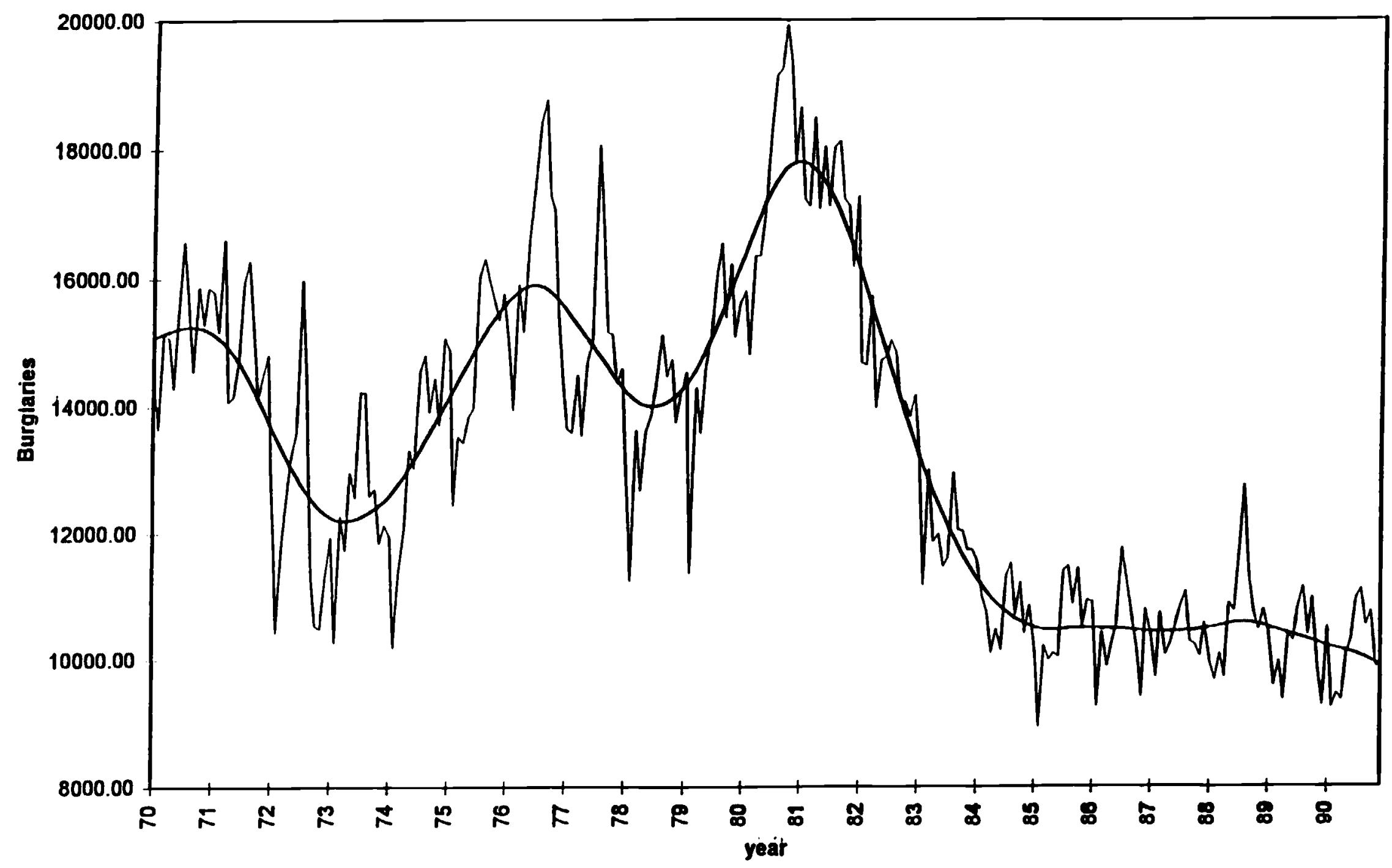




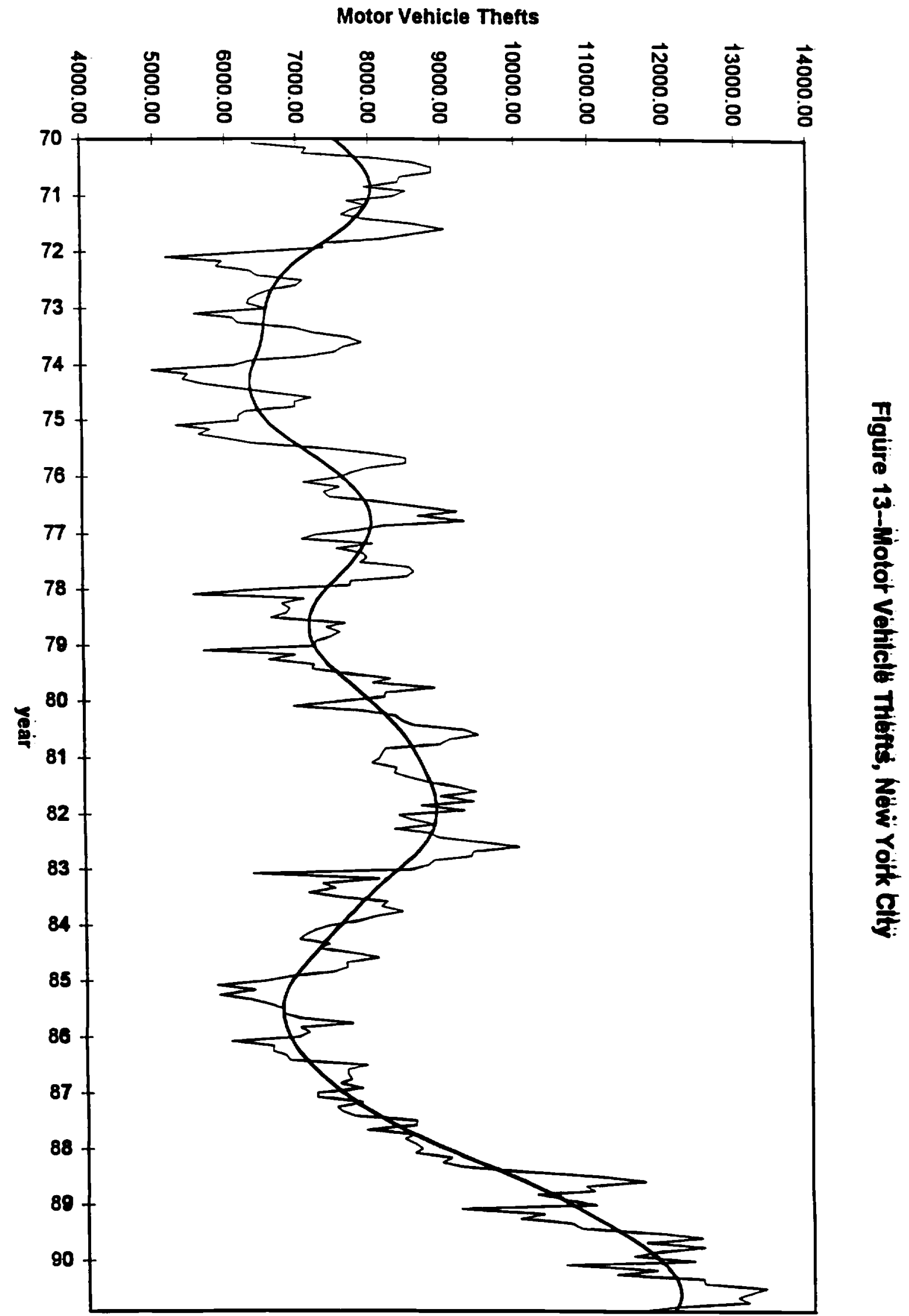




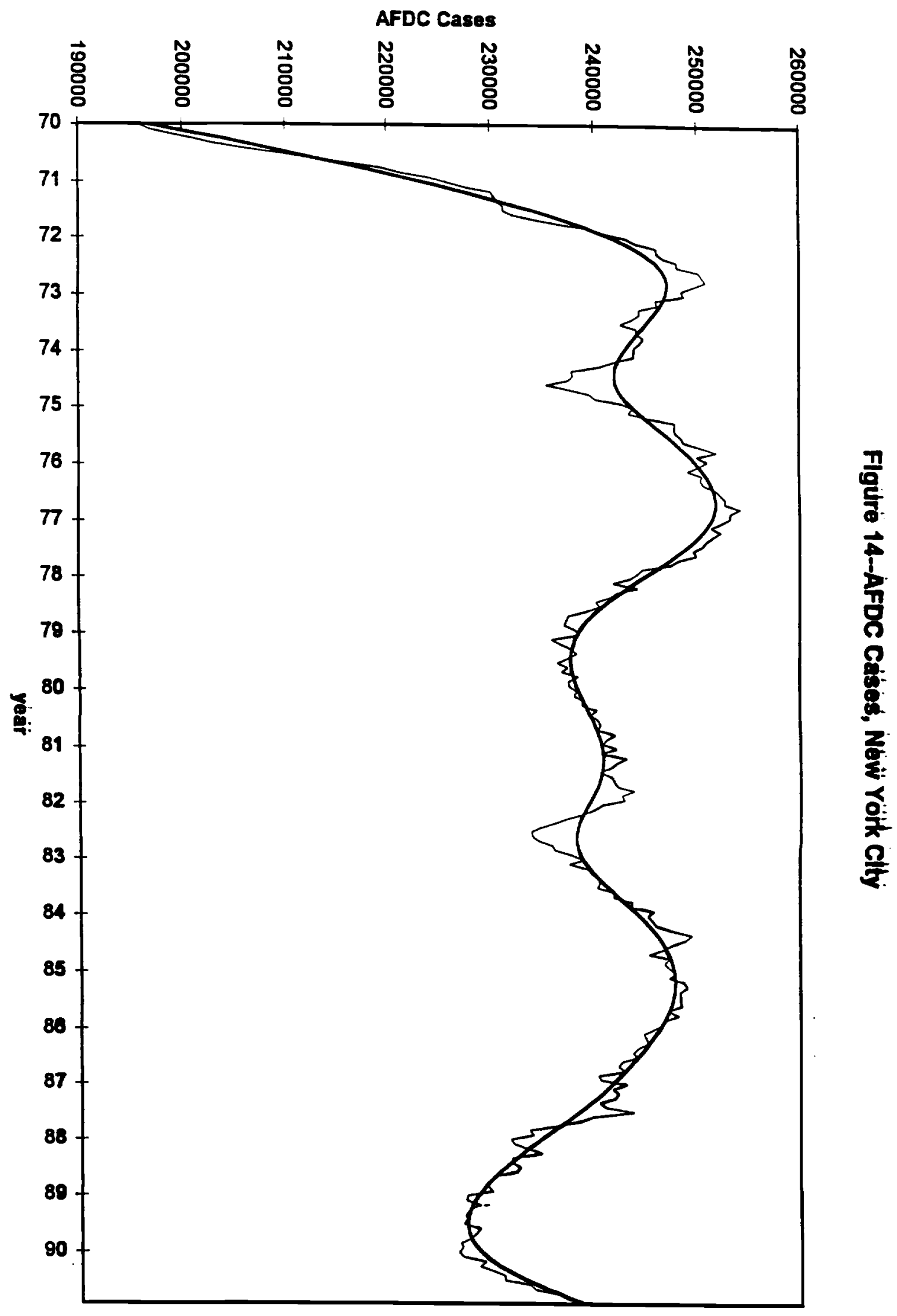

